\title{
Discovery of immunodominant T-cell epitopes reveals penton protein as a second immunodominant target in human adenovirus infection
}

Sabine Tischer ${ }^{1,2}$, René Geyeregger ${ }^{3}$, Julian Kwoczek ${ }^{1}$, Albert Heim ${ }^{4}$, Constanca Figueiredo ${ }^{1}$, Rainer Blasczyk ${ }^{1,2}$, Britta Maecker-Kolhoff ${ }^{2,5+}$ and Britta Eiz-Vesper ${ }^{1,2^{*}+}$

\begin{abstract}
Background: Human adenovirus (HAdV) infections remain a significant cause of morbidity and mortality after hematopoietic stem cell transplantation (HSCT). Efficient antiviral T-cell responses are necessary to clear infection, which is hampered by delayed immune reconstitution and medical immunosuppression after HSCT. Protective immunity may be conferred by adoptive transfer of HAdV-specific T cells. For identification of patients at risk and monitoring of treatment responses diligent assessment of anti-HAdV cellular immune responses is crucial. The HAdV-derived protein hexon has been recognized as a major immunodominant target across HAdV species. We aimed at identifying further targets of protective anti-HAdV immune response and characterizing immunogenic epitopes.

Methods: Nineteen candidate nonamers from hexon and penton proteins were identified by epitope binding prediction. Peptides were synthesized and tested for in vivo immunogenicity by screening peripheral blood mononuclear cells from healthy volunteers $(n=64)$ and HAdV-infected stem cell recipients $(n=26)$ for memory T cells recognizing the candidate epitopes in the context of most common HLA alleles.

Results: Functional $C D 8^{+} \mathrm{T}$ cells recognizing seven epitopes were identified, among them four penton-derived and

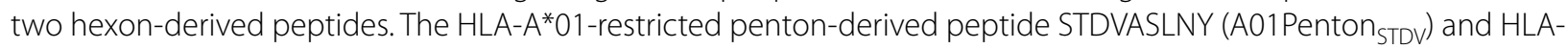
$A^{*} 02$-restricted hexon-derived peptide TLLYVLFEV $\left(A 02 H\right.$ exon $\left.{ }_{T L L Y}\right)$ were recognized by more than half of the persons carrying the respective HLA-type.

Conclusions: Thus, the HAdV-derived penton protein is a novel major target of the anti-HAdV immune response. Identification of new immunodominant epitopes will facilitate and broaden immune assessment strategies to identify patients suitable for T-cell transfer. Knowledge of additional target structures may increase T-cell recovery in manufacturing processes.
\end{abstract}

Keywords: Human adenovirus, Penton, T-cell epitope, T-cell monitoring, Immunotherapy

\section{Background}

Human adenovirus (HAdV) infection constitutes a major cause of morbidity and mortality in patients undergoing

\section{*Correspondence: eiz-vesper.britta@mh-hannover.de}

${ }^{\dagger}$ Britta Maecker-Kolhoff and Britta Eiz-Vesper contributed equally to this work

${ }^{1}$ Institute for Transfusion Medicine, Hannover Medical School,

Carl-Neuberg-Strasse 1, 30625 Hannover, Germany

Full list of author information is available at the end of the article allogeneic hematopoietic stem cell transplantation (HSCT). The incidence of HAdV infection ranges from 5 to $30 \%$, with pediatric recipients showing the highest rates of infection with up to $83 \%$ lethality [1-6]. Monitoring for HAdV infection and therapeutic intervention (reduction of immunosuppression, antiviral treatment) may reduce mortality due to HAdV in pediatric HSCT recipients [7]. However, antiviral treatments for HAdV infection with agents like cidofovir and ribavirin are 
associated with toxicity and may result in delayed immune reconstitution. Previous studies clearly indicate that $\mathrm{T}$ cells, the most potent effectors of the human immune system, are crucial for HAdV clearance [2]. It was demonstrated that children with HAdV-associated mortality had no HAdV-specific T cells, whereas patients who cleared HAdV infection showed HAdV-specific $T$-cell responses $[2,8]$. Adoptive transfer of HAdVspecific $T$ cells offers an effective and non-toxic immunotherapeutic strategy to reduce or prevent the clinical manifestation of HAdV in HSCT recipients with no or low numbers of HAdV-specific T cells [2, 8-12]. Monitoring HAdV-specific T-cell immunity may improve risk assessment in HSCT recipients and enhance treatment efficacy by determining the optimal time point for adoptive T-cell transfer. The median time between the first detection of HAdV DNA in the blood and the onset of symptoms is 3 weeks, which therefore seems to be the optimal time point for adoptive T-cell transfer [2, 13, 14]. Since the generation of short-term in vitro generated virus-specific T-cell lines takes about 3 weeks including quality controls, the production should start even earlier at the time of high viral load in stool $\left(>10^{6}\right.$ copies) [12, $15]$.

The 70 different human HAdV types identified to date are divided into seven species (A to G) [16, 17]. Type 31 (of species HAdV-A) and HAdV 1, 2, and 5 (of species $\mathrm{HAdV}-\mathrm{C}$ ) are the most prevalent types in HSCT recipients [4-7]. Occasionally, types of species HAdV-B can be observed in adult HSCT recipients [18]. The major capsid protein hexon serves as an immunodominant target antigen across the different HAdV types, but few hexon-derived epitopes have been identified as immunodominant so far [13, 19-23]. Most of these epitopes are highly conserved, demonstrating that HAdV-specific $\mathrm{T}$ cells can cross-react across HAdV species and may therefore provide protection against a wide range of HAdV types [20]. HAdV-specific T-cell responses to the recombinant hexon protein, the overlapping peptide pool covering the complete hexon sequence, HLArestricted peptides, and whole viral lysates have been investigated. A study by Feuchtinger et al. revealed that $10.5 \%$ of donors had a specific T-cell response to the whole adenovirus but no response to the hexon protein, while $17 \%$ of donors had no detectable T-cell response to HAdV [11]. Moreover, Zandvliet et al. detected specific $\mathrm{CD}^{+} \mathrm{T}$ cells in $6 / 16$ healthy donors $(37.5 \%)$ after stimulation with the 15 -mer hexon peptide pool, but only $3 / 16$ donors ( $18.8 \%$ ) had specific T cells for known $\mathrm{CD}^{+}$hexon epitopes [24]. Sukdolak et al. observed a specific T-cell response to the 15-mer hexon peptide pool in $73 \%$ of HAdV seropositive healthy donors, while $30 \%$ were classified as high responders and $43 \%$ as low responders [25]. Interestingly, $27 \%$ of all HAdV seropositive healthy donors tested showed no response to the hexon peptide pool. These results underline the need to identify more immunogenic T-cell epitopes to improve the selection of HAdV-specific $\mathrm{T}$ cells for adoptive transfer and the immunomonitoring of highrisk patients.

T-cell epitopes can be identified by direct or reverse immunology. Various computer algorithms have been developed over the past years that allow for the prediction of peptide binding to MHC class I and II molecules, proteasome cleavage patterns and transporter associated with antigen processing translocation [26]. Naturally presented $\mathrm{CD} 8^{+}$T-cell epitopes are usually among the topscoring 2 in $80 \%$ of all predictions, whereas the reliability of $\mathrm{CD}^{+}{ }^{+}$T-cell epitope prediction is much lower due to the more variable pocket binding behavior of MHC class II molecules [27]. SYFPEITHI [26, 28, 29], BIMAS $[26,30]$ and NetChop [31] are the most widely used algorithms to identify cytotoxic $\mathrm{T}$ lymphocyte (CTL) epitopes in viral, microbial, and tumor antigens. These well-established algorithms, which have been validated and compared [26], were employed in this study to predict new HAdV epitopes.

The major focus of this study was to identify and evaluate novel immunodominant HAdV-specific T-cell epitopes by analyzing the main structural proteins, hexon and penton. HLA-A*01-, A*02-, A*03- and B*08restricted peptide epitopes within conserved protein regions (Table 1) were pre-selected based on the predictions of several established computer algorithms. Immunogenicity of the top-ranked epitopes was investigated by established methods: IFN- $\gamma$-based EliSpot, cytokine secretion assay (CSA), peptide MHC (pMHC) multimer staining and multicolor flow cytometry. Four of the selected peptide candidates were classified as low immunodominant and two as high immunodominant according to the number of responders in the healthy donors and HAdV-infected HSCT recipients. This paper describes for the first time the immunogenic potential of penton-derived epitopes and demonstrates that the penton, as an immunological target, it is not secondary to the hexon. Expanding the repertoire of immunodominant HAdV-specific T-cell epitopes will enable more precise immunomonitoring and more effective multi-epitopebased T-cell therapy by targeting epitopes presented in a broader array of HLA molecules.

\section{Methods}

\section{Study population}

The current study has been approved by the Internal Review Board of Hannover Medical School. Following written informed consent peripheral blood was obtained 
Table 1 Predicted peptide candidates used for HAdV-specific T-cell screening in healthy donors

\begin{tabular}{|c|c|c|c|c|c|}
\hline HLA class I restriction & Sequence [aa] & Abbreviation & $\begin{array}{l}\text { HAdV species: type } \\
\text { [cross-reactivity] }\end{array}$ & $\begin{array}{l}\text { Responders } \\
\text { [EliSpot] }\end{array}$ & T-cell response [reference] \\
\hline HLA-A*01:01 & TDLGQNLLY & A01Hexon ${ }_{\text {TDLG }}$ & C: $1,2,5$ & $13 / 18$ & High $[13,20,21]$ \\
\hline HLA-A*01:01 & TNDQSFNDY & $\mathrm{A}_{01 \mathrm{Hexon}} \mathrm{TNDQ}_{\mathrm{N}}$ & $A: 31, B: 3, C: 1,2,5$ & $2 / 12$ & No [21] \\
\hline HLA-A*01:01 & QNDPTVVMY & A01Hexon ${ }_{\text {QNDP }}$ & A: 31 & $0 / 8$ & NA \\
\hline HLA-A*02:01 & TLLYVLFEV & A02Hexon TLLY & $A: 31, C: 1,2,5$ & $28 / 41$ & High $[13,22,23]$ \\
\hline HLA-A*02:01 & TLAVGDNRV & $\mathrm{AO2HexOn}_{\text {TLAV }}$ & $A: 31, B: 3, C: 1,2,5$ & $0 / 5$ & No [13] \\
\hline HLA-B*08:01 & GLRYRSMLL & $\mathrm{B} 08 \mathrm{Hexon}$ GLRY & $A: 31, B: 3, C: 1,2,5$ & $0 / 5$ & Minimal [20] \\
\hline HLA-B*08:01 & DLQDRNTEL & BOSHexon $_{D L Q D}$ & A: $31, B: 3, C: 1,2,5$ & $6 / 27$ & NA \\
\hline HLA-A*01:01 & STDVASLNY & A01Penton STDV $_{\text {ST }}$ & C: $1,2,5$ & $25 / 38$ & NA \\
\hline HLA-A*01:01 & SNDSTFTQY & A01Penton $_{\text {SNDS }}$ & C: $1,2,5$ & $0 / 8$ & NA \\
\hline HLA-A*01:01 & SSDIASLNY & A01Penton $_{\text {SSDI }}$ & A: 31 & $0 / 5$ & NA \\
\hline HLA-A*01:01 & LTDHGTLPL & A01Penton ${ }_{L T D H}$ & $A: 31, B: 3, C: 1,2,5$ & $0 / 5$ & NA \\
\hline HLA-A*02:01 & ILHTNMPNV & A02Penton ${ }_{I L H T}$ & A: $31, C: 1,2,5$ & $7 / 28$ & NA \\
\hline HLA-A*02:01 & ALGIVSPRV & A02Penton ${ }_{\mathrm{ALGl}}$ & $A: 31, C: 1,2,5$ & $0 / 6$ & NA \\
\hline HLA-A*02:01 & GNIPALLDV & A02Penton ${ }_{G N I P}$ & $A: 31, B: 3, C: 1,2,5$ & $0 / 6$ & NA \\
\hline HLA-A*03:01 & VLESDIGVK & A03Penton ${ }_{\text {VLES }}$ & $A: 31, B: 3, C: 1,2,5$ & $0 / 6$ & NA \\
\hline HLA-A*03:01 & LLPGCGVDF & A03Penton ${ }_{L L P G}$ & $A: 31, B: 3, C: 1,2,5$ & $0 / 6$ & NA \\
\hline HLA-B*08:01 & NTKYRSWYL & B08Penton $_{\text {NTKY }}$ & A: 31 & $0 / 7$ & NA \\
\hline HLA-B*08:01 & DSKGRSYNL & BOsPenton $_{D S K G}$ & A: 31 & $9 / 36$ & NA \\
\hline HLA-B*08:01 & LTKDKQVEL & B08Penton $_{L T K D}$ & $C: 1,2$ & $0 / 5$ & NA \\
\hline HLA-B*08:01 & DSKKRSYNL & BO8Penton $_{\text {DSKK }}$ & $C: 1,2,5$ & $15 / 36$ & NA \\
\hline
\end{tabular}

Names, sequences and abbreviations of 19 epitope candidates (plus one reference epitope, A01Hexon ${ }_{\text {TDLG }}$ ) predicted for frequent HLA class I alleles and clinically relevant HAdV types. The immunogenicity of epitope candidates was evaluated by pre-screening HAdV-specific T-cell responses to the 19 synthesized peptides in healthy donors using IFN- $\gamma$ Elispot assay. Seven of 19 peptide candidates induced HAdV-specific T-cell responses, six of which (highlighted in italic) were classified as immunodominant. The following epitope sequences were published elsewhere: A01 Hexon ${ }_{\mathrm{TDLG}}[13,20,21], \mathrm{A} 1 \mathrm{HexOn}_{\mathrm{TNDQ}}[21], \mathrm{A}_{02} \mathrm{HexOn}_{\mathrm{TLY}}[13,22,23]$,

A02Hexon $_{\text {TLAV }}[13]$, and B08Hexon ${ }_{\text {GLRY }}$ [20] (NA not applicable)

from 64 healthy platelet donors from the Hannover Medical School (MHH) Institute for Transfusion Medicine and 26 pediatric patients after HSCT with detectable HAdV-DNA in blood and/or stool. Healthy donors had no prior history of blood transfusion and no signs of acute infection. All donors and patients were typed for HLA class I and class II alleles at the four-digit level by sequence-based typing [32]. Informed consent was obtained from all donors and patients as approved by the Ethics Committee of Hannover Medical School, and trial subject data were treated as confidential information protected by medical confidentiality.

\section{Epitope prediction}

HAdV hexon and penton protein sequences restricted to the types 1, 2, 3, 5, and 31 were obtained from the SwissProt database (http://www.uniprot.org). Epitope prediction programs SYFPEITHI (http://www.syfpeithi. de) [28, 29], BIMAS (http://www.bimas.cit.nih.gov) [30], and NetChop (http://www.cbs.dtu.dk) [31] were used to predict nonamers capable of binding to HLA- A*01:01, A*02:01, $A^{*} 03: 01$ and $B * 08: 01$ molecules (Fig. 1). Epitope candidates were only selected if identified by all programs according to their predictive scores (Table 1). The $\mathrm{N}_{\mathrm{ET}}$ $\mathrm{MHC}_{\mathrm{STAB}}$ [33], $\mathrm{N}_{\mathrm{ET}} \mathrm{MHC}$, and $\mathrm{N}_{\mathrm{ET}} \mathrm{MHC}_{\text {cons }}$ (Fig. 1) prediction algorithms provided by the Center for Biological Sequence Analysis (CBS, http://www.cbs.dtu.dk) was used to predict the stability of pMHC complexes for all database-available HLA types.

\section{Synthetic peptides and peptide pools}

Peptides of the 19 top-scoring epitope candidates (Table 1) were synthesized (China Peptides, Shanghai, China; ProImmune, Oxford, UK) and used for pre-screening and T-cell immunoassays (Fig. 1). The overlapping peptide pools of hexon (HAdV5Hexon ${ }_{p p}$, Miltenyi Biotec, Bergisch Gladbach) and penton (HAdV5Penton $_{p p}$, Miltenyi Biotec) were further used as stimuli of antiviral memory $\mathrm{T}$ cells. The HLA-A*01-restricted hexon-derived peptide TDLGQNLLY (A01Hexon ${ }_{\text {TDLG }}$, ProImmune, Table 1) was used as a positive control. Peptide binding assays were performed using two additional HLA-restricted peptides from phosphoprotein 65 (pp65) of the human cytomegalovirus (YSEHPTFTSQY: A01pp65 $5_{\text {YSEH }}$ and NLVPMVATV: A02pp65 ${ }_{\text {NLVP }}$, ProImmune) as positive controls. 


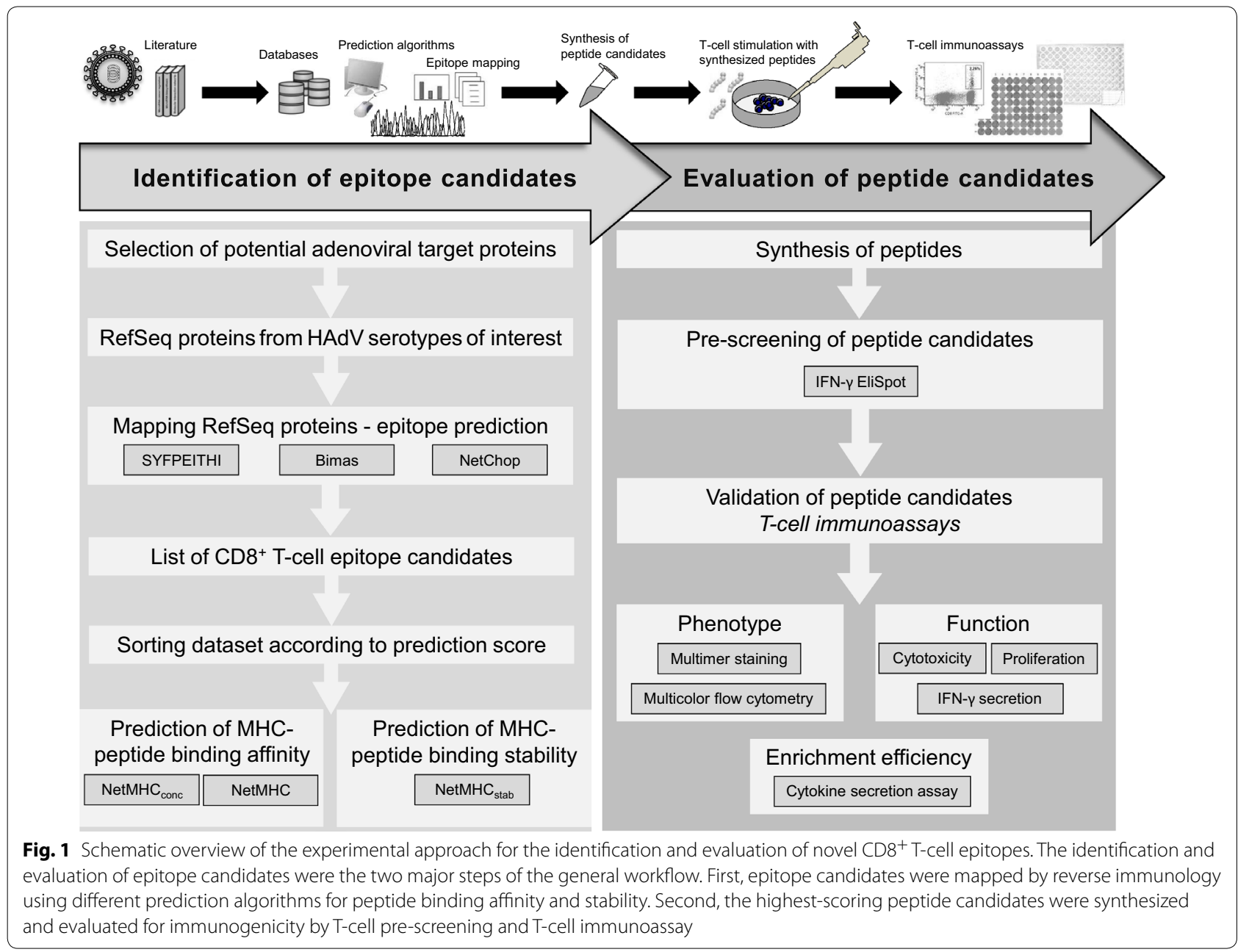

\section{HLA class I peptide binding assay}

The T2 peptide binding assay was performed with the HLA-A*01- and HLA-A*-02-restricted peptide candidates as described previously [34]. To determine peptide binding to HLA-A*01:01 molecules, T2 cells were transfected to express membrane-bound HLA-A*01:01 [35]. Briefly, $1 \times 10^{6} \mathrm{~T} 2$ cells $/ \mathrm{ml}$ were pulsed with $50 \mu \mathrm{g} / \mathrm{ml}$ peptide (Table 1) and $5 \mu \mathrm{g} / \mathrm{ml}$ beta- 2 microglobulin ( $\beta 2 \mathrm{~m}$, Sigma, St Louis, MO, US) in serum-free medium for $15-18 \mathrm{~h}$ at $37{ }^{\circ} \mathrm{C}$. T2 cells incubated without peptide served as controls. HLA expression levels were determined by flow cytometry (FACSCanto II and FACSDiva V6.1.2 software, BD Biosciences, San Jose, CA) using the monoclonal antibodies (mAb) HLA-ABC fluorescein (FITC, w6/32, AbD Serotec, Ltd-Kidlington, UK) and anti-HLA-A*02 phycoerythrin (PE, BB7.2, Biolegend, San Diego, CA, US).

\section{Screening for HAdV peptide-specific HLA-restricted T cells} The IFN- $\gamma$ EliSpot assay was used for peptide screening to enumerate HAdV-specific IFN- $\gamma$-producing $\mathrm{T}$ cells $[25$,
36]. Briefly, peripheral blood mononuclear cells (PBMCs) were plated at a density of $2.5 \times 10^{5}$ cells/well in triplicate wells and incubated overnight in the presence of the investigated peptides $(10 \mu \mathrm{g} / \mathrm{ml})$ and peptide pools $(1 \mu \mathrm{g}$ per peptide/ml). PBMCs cultured with medium alone or in the presence of $1 \mu \mathrm{g} / \mathrm{ml}$ staphylococcal enterotoxin B (SEB, Sigma-Aldrich, Hamburg, Germany) served as negative and positive controls, respectively. Spots of IFN- $\gamma$ positive cells were counted and analyzed and the results were expressed as the number of spots per well (spw). The mean number of spots in the negative control was subtracted from the mean number of spots in the antigen wells. The cut-off value for a positive response was $\geq 5$ spw in healthy donors and $\geq 2$ spw in HAdV-infected patients.

\section{T-cell proliferation assay}

The proliferative capacities of HAdV-specific $\mathrm{T}$ cells induced by the various peptide candidates (Table 1, highlighted in italic) were analyzed by carboxyfluorescein 
succinimidyl ester (CFSE) dilution assay (Invitrogen, Darmstadt, Germany). $5 \times 10^{5}$ CFSE-labeled PBMCs were stimulated with $10 \mu \mathrm{g} / \mathrm{ml}$ peptide for 7 days. Unstimulated $\mathrm{T}$ cells were used as negative controls. Spontaneous T-cell proliferation in unstimulated controls was subtracted from the specific values in peptide-stimulated cultures. Cells were stained with allophycocyanin (APC)-conjugated anti-CD8 $\mathrm{mAb}$ and PE-Cy7-conjugated anti-CD3 mAb (all BD Biosciences). The distribution of viable and dead cells was analyzed by 7-amino-actinomycin D (7-AAD) staining (BD Biosciences). At least 50,000 events were acquired in the 7-AAD ${ }^{-}$gate. $\mathrm{CFSE}^{+/-} \mathrm{CD}^{+}$and $\mathrm{CFSE}^{+/-} \mathrm{CD}^{+}$T-cell populations were gated based on the scatter properties of viable $7-\mathrm{AAD}^{-} \mathrm{CD}^{+}$or $7-\mathrm{AAD}^{-} \mathrm{CD}^{+}{ }^{+} \mathrm{CD} 8^{+} \mathrm{T}$ lymphocytes.

\section{Immunophenotyping and detection of HAdV-specific T cells}

A comprehensive analysis of the phenotype and specificity of HAdV-specific $\mathrm{T}$ cells was performed with freshly isolated PBMCs and in vitro expanded HAdV-specific T cells. PBMCs from healthy donors were stimulated for 7 days with $10 \mu \mathrm{g} / \mathrm{ml}$ peptide (Table 1 , highlighted in italic), and restimulated for another 7 days with irradiated autologous peptide-loaded PBMCs. Flow cytometric analysis of the $\mathrm{CD} 8^{+} \mathrm{T}$-cell phenotype was performed using cells stained with the mAbs anti-CD3 peridinin chlorophyll protein (PerCP), anti-CD8 APC (BD Biosciences), anti-CD19 FITC, anti-CD62L APC-Cy7, and anti-CD45RA PE-Cy7 (BioLegend) to assess the frequencies of naïve $\mathrm{T}$ cells $\left(\mathrm{T}_{\mathrm{N}} ; \mathrm{CD} \mathrm{CL}^{+} \mathrm{CD} 45 \mathrm{RA}^{+}\right)$, central memory $\mathrm{T}$ cells $\left(\mathrm{T}_{\mathrm{CM}} ; \mathrm{CD} \mathrm{CL}^{+} \mathrm{CD}^{+} 5 \mathrm{RA}^{-}\right)$, effector memory $\mathrm{T}$ cells $\left(\mathrm{T}_{\mathrm{EM}}\right.$; $\left.\mathrm{CD} 62 \mathrm{~L}^{-} \mathrm{CD}^{-} 5 \mathrm{RA}^{-}\right)$, and terminally differentiated effector memory $\mathrm{T}$ cells $\left(\mathrm{T}_{\mathrm{EMRA}}\right.$; $\left.\mathrm{CD} 2 \mathrm{~L}^{-} \mathrm{CD} 45 \mathrm{RA}^{+}\right)$.

In addition, specificities and frequencies of $\mathrm{CD}^{+} \mathrm{T}$ cells against the peptide candidates A01Penton ${ }_{S T D V}$, $\mathrm{A} 02 \mathrm{Hexon}_{\mathrm{TLLY}}$, and the positive control A01Hexon ${ }_{\mathrm{TDLG}}$ (Table 1) were detected by pMHC multimer staining using R-PE-conjugated multimeric Pro5 pentamers (ProImmune). At least 100,000 events were acquired in the lymphocyte gate, which was set based on the light scatter properties scatter properties of lymphocytes and on $\mathrm{CD}^{+}$T-cell populations. To be considered positive, the sample had to (1) be a well-defined cell population and/ or (2) contain $\geq 0.3 \%$ pentamer ${ }^{+} \mathrm{CD}^{+} \mathrm{T}$ cells.

\section{Cytotoxic activity of peptide-induced HAdV-specific T cells}

The cytotoxicity of in vitro expanded peptide-specific $\mathrm{T}$ cells (day 14) was assessed in a non-radioactive flow cytometric assay using autologous CFSE-labeled peptide-loaded PBMCs as target cells. In order to exclude alloreactivity, unloaded CFSE-labeled PBMCs were further used as target cells, in which the basal cytotoxic activity of effector $\mathrm{T}$ cells against the unloaded target cells was subtracted from the specific cytotoxic values. Briefly, effector T cells were incubated with target cells at effector to target (E:T) ratios of 10:1, 30:1 and 60:1. Target cell lysis was assessed after $5 \mathrm{~h}$ using 7-AAD staining.

In addition, antiviral T-cell degranulation was determined as a surrogate marker of cytotoxicity by testing for CD107a cell surface expression by flow cytometry. In vitro expanded HAdV-specific $\mathrm{T}$ cells were incubated with $10 \mu \mathrm{g} / \mathrm{ml}$ peptide and $\mathrm{PE}-\mathrm{Cy} 7$-conjugated anti$\mathrm{CD} 107 \mathrm{a}$ mAb (BioLegend) at $37^{\circ} \mathrm{C}$ and $5 \% \mathrm{CO}_{2}$. After $1 \mathrm{~h}$ of incubation, monensin (1:1000, BioLegend) was added and cells were incubated for further $4 \mathrm{~h}$ before staining with anti-CD3 PerCP and anti-CD8 APC.

\section{Enrichment of HAdV peptide-specific T cells}

The enrichment efficiency of in vitro expanded HAdV peptide-specific $\mathrm{T}$ cells (day 14) was assessed using the cytokine secretion assay (Miltenyi Biotec). Aliquots of cell fractions before enrichment ("Origin") and after enrichment ("Eluate") were used for detailed analysis of IFN- $\gamma$-secreting viable HAdV-specific T-cell subsets by multicolor flow cytometry. In addition to anti-IFN- $\gamma$ PE (Miltenyi Biotec), cells were stained with anti-CD45 APC-Cy7, anti-CD56 PE-Cy7, anti-CD3 FITC, anti-CD8APC mAbs, and 7-AAD (all BD Biosciences). At least 10,000 events were acquired in the viable $\mathrm{CD} 45^{+} 7 \mathrm{AAD}^{-}$ leukocyte gate.

\section{Statistical analysis}

Statistical analysis was performed using the Prism v5.02 software (GraphPad, San Diego, California, USA). The results are displayed as mean \pm standard deviation (SD). Generated data were analyzed using non-parametric Mann-Whitney U test. Significance levels were calculated and expressed as $\mathrm{p}$ values $(* \mathrm{p}<0.05$, ** $\mathrm{p}<0.01$, $\stackrel{* * * * 0}{*}<0.001)$.

\section{Results}

\section{Selection of potential HLA-restricted peptide epitopes} within hexon and penton protein

A total of 947 hexon- and penton-derived epitope candidates restricted to HLA-types $\mathrm{A} * 01, \mathrm{~A}^{*} 02, \mathrm{~A}^{*} 03$, and $B^{*} 08$ were identified by the computer algorithms SYFPEITHI, BIMAS, and NetChop (Fig. 1). Nineteen (2\%) of the highest scoring sequences (six HLA-A*01-, five HLA-A*02-, two HLA-A*03-, and six HLA-B*08-resticted peptides; Table 2, [13, 20-23]) were synthesized. All three algorithms yielded comparably high prediction scores for seven of the 19 peptide epitopes (A02Hexon $_{\text {TLLY }}$, B08Hexon $_{\text {GLRY }}$, A01Penton $_{\text {STDV }}$, A01Penton $_{\text {SSDI }}$, 


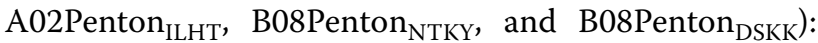
the SYFPEITHI score was 23-35, the BIMAS rank 1-2, and NetChop rating "strong binder (SB)" (Table 2). In comparison to the known immunodominant peptide epitopes of HAdV (A01Hexon TDLG $_{\text {) }}$ ) and of cytomegalovirus (A01pp65 $5_{\mathrm{YSEH}}$, and A02pp65 $5_{\mathrm{NLVP}}$ ), we detected (Additional file 1: Figure S1A) the highest binding affinity for A01Penton STDV $_{\text {(FI 0.13), A01Penton }}$ SSDI (FI 0.11), A02Penton $_{\text {ILHT }}$ (FI 1.29) and A02Penton ALGI $_{\text {(FI 1.29) }}$ by in vitro T2 peptide binding assay. The peptide binding results generated by computer and in vitro analyses were comparable. Because immunodominant peptides bound to HLA molecules were shown to be more stable than non-immunogenic peptides [33,37], we further investigated the peptide-HLA class I stability of peptides of the database-available HLA types $\mathrm{A}^{* 01}, \mathrm{~A}^{* 0} 02$, and

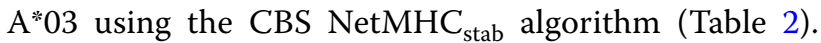
HLA class I peptide complexes with a predicted half-life $\left(t_{1 / 2}\right)>2 \mathrm{~h}$ are defined as very stable [33]. This criterion was met by $7 / 14$ epitopes $(50 \%)$ restricted to HLA$\mathrm{A}^{* 01} 01,-\mathrm{A}^{*} 02$, and $-\mathrm{A}^{*} 03$, including two highly stable (HS, $t_{1 / 2} \geq 6 \mathrm{~h}$ ) and five weakly stable (WS, $\mathrm{t}_{1 / 2} \geq 2 \mathrm{~h}$ ) epitopes.

\section{Identification of specific IFN- $\gamma$ responses to the HAdV peptide candidates}

Our analysis of specific memory T-cell responses to the control antigens HAdV5Hexon ${ }_{\mathrm{pp}}$ HAdV5Penton $_{\mathrm{pp}}$, and

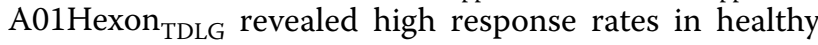
donors (Fig. 2a) and HAdV-infected HSCT recipients (Fig. 2b). A total of 19 peptide candidates were selected and analyzed by IFN- $\gamma$ EliSpot for their capacity to induce HAdV-specific T-cell responses. Seven elicited a specific T-cell response, defined by a cut-off of $\geq 5 \mathrm{spw}$ (Table 1). The response rates ranged from 16.7 to $65.8 \%$ (Fig. 2a). Pre-classification of peptide candidates into

Table 2 Prediction results for the investigated HAdV epitope candidates

\begin{tabular}{|c|c|c|c|c|c|}
\hline \multirow[t]{3}{*}{ Abbreviation } & \multicolumn{5}{|l|}{ Prediction score } \\
\hline & \multirow[t]{2}{*}{ SYFPEITHI [score] } & \multirow[t]{2}{*}{ BIMAS [rank] } & \multicolumn{3}{|l|}{ NetChop } \\
\hline & & & NetMHC cons $[B L]^{b}$ & NetMHC $[B L]^{b}$ & $\begin{array}{l}\text { NetMHC } \\
{[S L]^{c}, T_{1 / 2}^{a}}\end{array}$ \\
\hline A01Hexon ${ }_{\text {TDLG }}$ & 20 & 0.125 [134] & 11052.58 & 13301 & 0.63 \\
\hline A01Hexon ${ }_{\text {TNDQ }}$ & 28 & $6.25[11]$ & $677.84[S B]$ & 1182 & 2.08 [WS] \\
\hline A01Hexon ${ }_{\mathrm{QNDP}}$ & 27 & $125[1]$ & 1691.19 [WB] & 3899 & $2.97[\mathrm{WS}]$ \\
\hline $\mathrm{AO2HexOn}_{T L L Y}$ & 27 & $3432.948[1]$ & $3.25[S B]$ & $3[S B]$ & $14.1[\mathrm{HS}]$ \\
\hline A02Hexon ${ }_{\text {TLAV }}$ & 25 & $69.552[15]$ & 649.13 & 513 & 1.09 \\
\hline B08Hexon $_{G L R Y}$ & 32 & $160[1]$ & $42.02[S B]$ & $40[S B]$ & - \\
\hline B08Hexon $_{D L Q D}$ & 26 & $24[2]$ & 2339.71 & 3791 & - \\
\hline A01Penton $_{\text {STDV }}$ & 35 & $312.5[1]$ & $5.9[\mathrm{SB}]$ & $7[\mathrm{SB}]$ & $4.86[\mathrm{WS}]$ \\
\hline A01Penton $_{\text {SNDS }}$ & 28 & $6.25[8]$ & $953.12[\mathrm{WB}]$ & 2784 & 1.74 \\
\hline A01Penton $_{\mathrm{SSDI}}$ & 33 & $187.5[1]$ & $8.07[S B]$ & $9[S B]$ & $4.23[\mathrm{WS}]$ \\
\hline A01Penton ${ }_{\mathrm{LTDH}}$ & 21 & $6.25[9]$ & $43.65[S B]$ & $30[S B]$ & 1 \\
\hline A02Penton $_{I L H T}$ & 23 & 271.948 [2] & $16.75[S B]$ & $18[S B]$ & $5.72[W S]$ \\
\hline A02Penton $\mathrm{ALGl}$ & 23 & $69.552[5]$ & 69.13 [WB] & $64[\mathrm{WB}]$ & $7.77[\mathrm{HS}]$ \\
\hline A02Penton $_{\mathrm{GNIP}}$ & 20 & $>20$ & 16673.41 & 17051 & 0.5 \\
\hline A03Penton VLES & 25 & $9[4]$ & 1073.58 & 1099 & 0.7 \\
\hline A03Penton ${ }_{L L P G}$ & 23 & $3[5]$ & 27426.93 & 21324 & 0.22 \\
\hline B08Penton $_{\text {NTKY }}$ & 29 & $80[2]$ & $39.6[S B]$ & $26[S B]$ & - \\
\hline BosPenton $_{D S K G}$ & 28 & $160[1]$ & 755.3 [WB] & 799 & - \\
\hline B08Penton $_{\text {LTKD }}$ & 32 & $120[2]$ & 2134.13 & 4050 & - \\
\hline BO8Penton $_{\text {DSKK }}$ & 28 & $160[1]$ & 130.88 [SB] & 80 [WB] & - \\
\hline
\end{tabular}

Prediction results for 19 epitope candidates (plus one reference epitope, A01 Hexon ${ }_{\text {TDLG }}$ ) predicted for frequent HLA class I alleles and clinically relevant HAdV types using three different prediction tools (SYFPETHI, BIMAS, and NetChop). Epitope candidates were selected with respect to their predicted HLA binding affinity ( $B L$ binding level) and peptide-HLA complex stability ( $S L$ stability level). Epitopes were classified as weak binders (WB threshold $500 \mathrm{nM}$ ) or strong binders ( $S B$ threshold $50 \mathrm{nM}$ ) with either weak stability (WS threshold $2 \mathrm{~h}$ ) or high stability (HS threshold $6 \mathrm{~h}$ ) according to the predicted scores.

Pre-classified immunodominant peptide candidates are highlighted in italic

a Estimated half-time $\left(\mathrm{t}_{1 / 2}\right)$ of dissociation (in hours)

b Estimated peptide binding affinity to HLA alleles as $I C_{50}$ value (in $n M$ )

${ }^{c}$ Estimated stability of peptide-MHC I complexes as $\mathrm{IC}_{50}$ value (in $\mathrm{nM}$ ), and $\mathrm{IC}_{50}=$ half-maximum inhibitory concentration 

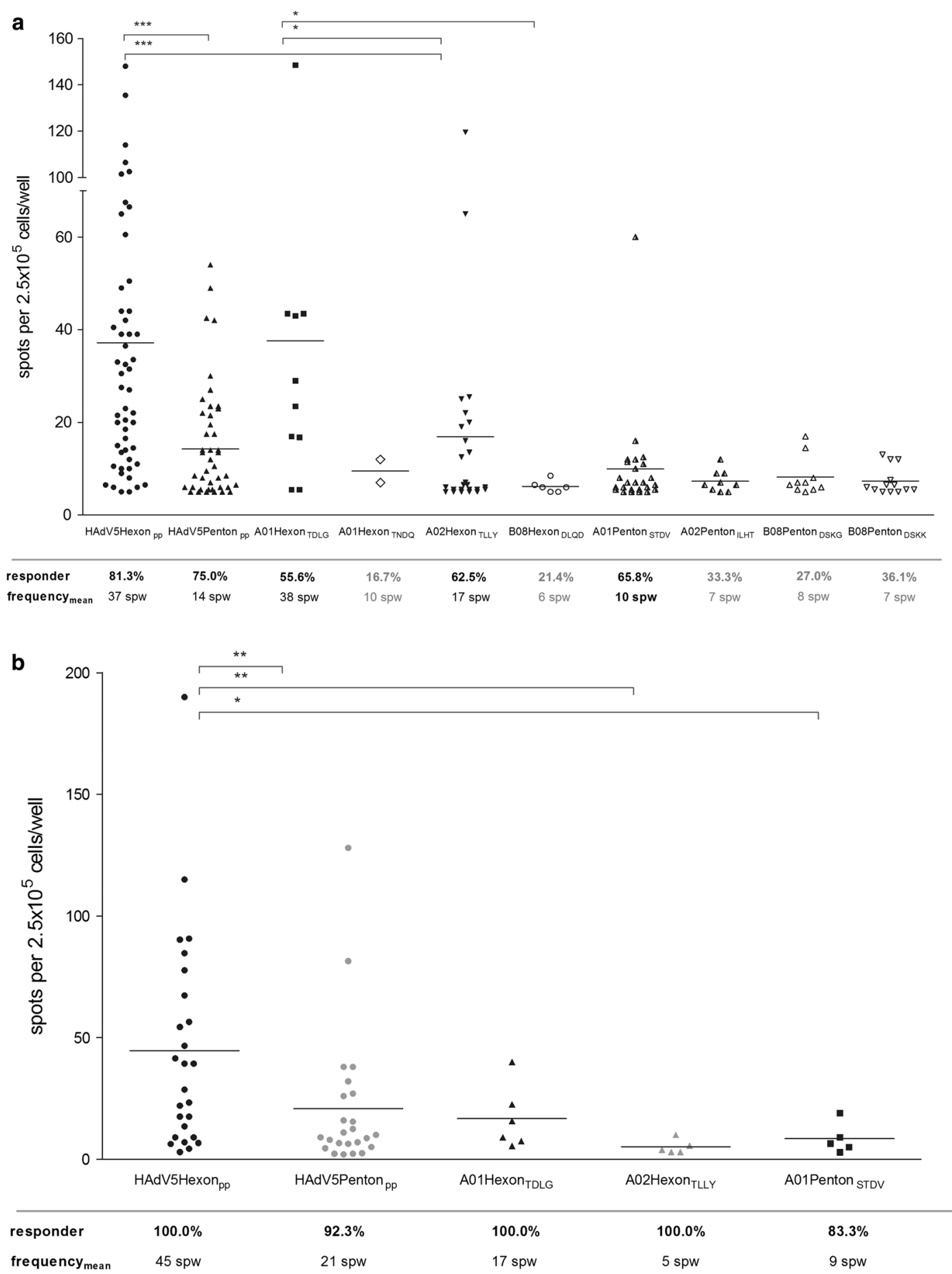

Fig. 2 Screening of HAdV-specific T-cell responses by IFN- $\gamma$ EliSpot. a IFN- - EliSpot was performed in 64 healthy donors to evaluate specific T-cell responses to overlapping HAdV hexon (HAdV5Hexon ${ }_{p p}$ ) and penton peptide pools (HAdV5Penton ${ }_{p p}$ ), four hexon-derived peptides (A01Hexon ${ }_{T D L G}$,

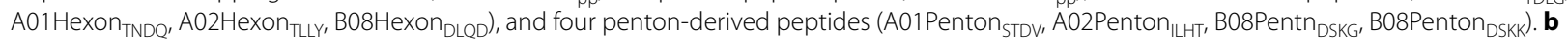
IFN- $\gamma$ EliSpot analysis of 26 HAdV-infected HSCT recipients for specific T-cell responses to overlapping HAdV hexon (HAdV5Hexon pp ) and penton

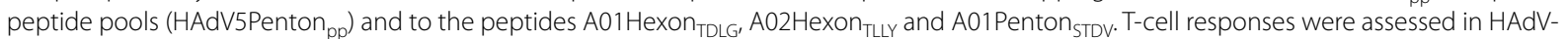
infected post-transplant patients. The highest T-cell response is shown for each tested patient. PBMCs cultured with medium alone or in the presence of $1 \mu \mathrm{g} / \mathrm{ml}$ staphylococcal enterotoxin B (SEB) served as negative and positive controls, respectively. IFN- $\gamma$ EliSpot results are expressed as the number of IFN- $\gamma$ spots per well (spw). The cut-off value for a positive response was $\geq 5$ spw in healthy donors and $\geq 2$ spw in HAdV-infected HCST recipients. Only data and mean frequencies from positive responder are shown. Asterisks indicate statistically significant differences between the antigens $\left({ }^{*} p<0.05,{ }^{* *} p<0.01,{ }^{* * *} p<0.001\right)$ 
non-immunodominant or immunodominant was performed according to the number of responders ( $\geq 20 \%)$.

The $\mathrm{A}^{01 \mathrm{Hexon}_{\mathrm{TNDQ}}}$ was pre-classified as nonimmunodominant (16.7 \% responder), whereas peptides B08Hexon DLQD $_{\text {, A02Penton }}$ ILHT, B08penton DSKG $_{\text {, }}$ B08Penton $_{\text {DSKK }}(\mathrm{n}=4$, Table 1$)$ were pre-classified as low immunodominant. $\mathrm{T}$ cells from $\geq 50 \%$ of healthy donors recognized the peptides A02Hexon ${ }_{\text {TLLY }}$ and A02PentonSTDV and were therefore pre-classified as highly immunodominant. The mean number of IFN $-\gamma^{+}$spots ranged from 6 to $17 \mathrm{spw}$, and was highest for A02Hexon ${ }_{\text {TLLY }}$ (17 spw) and A01Penton ${ }_{\text {STDV }}$ (mean $10 \mathrm{spw}$ ).

The response to the hexon control antigens (HAd$\mathrm{V} \mathrm{Hexon}_{\mathrm{pp}}$ : $81.3 \%$ responder, $37 \mathrm{spw}$; $\mathrm{A} 1 \mathrm{Hexon}_{\mathrm{TDLG}}$ : $55.6 \%$ responder, $38 \mathrm{spw}$ ) was comparably high in healthy donors. For HAdV5Penton ${ }_{\mathrm{pp}}$ we found a positive $\mathrm{T}$-cell response in $75 \%$ of donors (14 spw) and T-cell frequencies which were not significantly higher compared to the new A01Penton ${ }_{\text {STDV }}$ epitope.

In HAdV-infected HSCT patients, the immunogenicity of both peptide epitopes A02Hexon ${ }_{\text {TLLY }}$ and A01Penton $_{\text {STDV }}$ was further assessed to confirm their clinical relevance (Fig. 2b). Specific T-cell responses against the control antigens HAdV5Hexon ${ }_{\mathrm{pp}}$ (45 spw) and A01Hexon $_{\text {TDLG }}(17 \mathrm{spw})$ were found in $100 \%$ of patients. All HLA-A*02-positive patients (5/5) developed a HAdV-

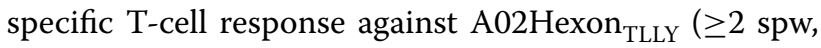
$5 \mathrm{spw})$. For A01Penton ${ }_{\text {STDV }}$ we found a positive T-cell response in $5 / 6(83.3 \%$ ) of patients ( 9 spw), while $24 / 26$ $(92.3 \%)$ of all patients developed a HAdV5Penton ${ }_{\mathrm{pp}}{ }^{\text {-spe- }}$ cific T-cell response (21 spw).

Comparing both overlapping peptide pools, T-cell responses to hexon were significantly higher (healthy donors: 2.6-fold, patients: 2.1 -fold) than those to penton. Furthermore, $\mathrm{T}$ cells from most donors and patients recognized HAdV5Hexon $_{\mathrm{pp}}$ and A01Hexon ${ }_{\mathrm{TDLG}}$ at higher frequencies than A02Hexon ${ }_{\mathrm{TLLY}}$, but showed no significant frequency differences between HAdV5Penton ${ }_{p p}$ and the peptide candidate A01Penton ${ }_{\text {STDV }}$.

\section{Validation of pre-classified immunodominant adenoviral CTL epitopes}

To find the optimal concentrations of the six pre-classified immunodominant peptides (Table 1, highlighted in italic) for T-cell immunoassays, we determined the sensitizing peptide concentration required to elicit $50 \%$ of maximal T-cell responses $\left(\mathrm{SD}_{50}\right)$ using the IFN- $\gamma$ EliSpot assay (Fig. 1; Additional file 1: Figure $\mathrm{S} 1 \mathrm{~B})$. The $\mathrm{SD}_{50}$ ranged from 5 to $10 \mu \mathrm{g} /$ $\mathrm{ml}$ for B08Hexon $\mathrm{DLQD}_{\mathrm{DL}}(\mathrm{n}=2)$ and B08Penton DSKG $_{(\mathrm{n}}(\mathrm{n})$, and from $10 \mu \mathrm{g} / \mathrm{ml}$ to $50 \mu \mathrm{g} / \mathrm{ml}$ for A02Hexon $\operatorname{TLLY}_{\text {TL }}(\mathrm{n}=3)$, A01Penton $_{\text {STDV }}(\mathrm{n}=2)$, A02Penton $_{\text {ILHT }}(\mathrm{n}=2)$, and B08Penton $_{\text {DSKK }}(\mathrm{n}=2)$. Therefore, T-cell immunoassays were performed at a final peptide concentration of $10 \mu \mathrm{g} / \mathrm{ml}$.

\section{Highly proliferative capacity of peptide-induced HAdV-specific T cells}

The proliferation profile of HAdV-specific $\mathrm{T}$ cells in

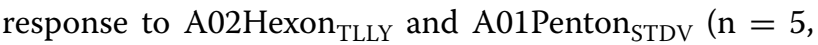
Fig. 3a) was assessed 7 days after in vitro stimulation. A mean frequency of $33.3 \% \mathrm{CFSE}^{\text {low }} \mathrm{CD}^{+}(\mathrm{A} 02 \mathrm{Hex}-$ on $_{\text {TLLY }}$ : mean $45.5 \%$, A01Penton ${ }_{\text {STDV }}$ : mean $\left.21.1 \%\right)$ and $\mathrm{CFSE}^{\text {low }} \mathrm{CD}^{+}{ }^{+} \mathrm{CD}^{+}{ }^{+} \mathrm{T}$ cells $\left(\mathrm{A} 02 \mathrm{Hexon} \mathrm{TLLY}_{\mathrm{T}}\right.$ : mean $19.4 \%$, A01Penton $_{\text {STDV: }}$ mean $47.2 \%$ ) was detected, while A01Penton ${ }_{S_{T D V}}$-stimulation resulted in 2.4-fold higher $\mathrm{CD}^{+} \mathrm{CD}^{+}$T-cells proliferation $(\mathrm{p}<0.05)$ than A02Hexon $_{\text {TLLY }}$. The other peptide candidates also resulted in high T-cell proliferation capacities (Table 1; Additional file 2:

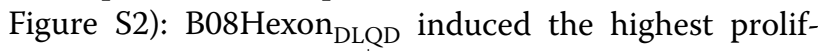
erative capacity of $\mathrm{CD}^{+} \mathrm{T}$ cells (mean $52.9 \%$ ), while B08Penton $_{\text {DSKK }}$ induced the highest $\mathrm{CD}^{+} \mathrm{CD}^{+}$T-cell proliferation (mean $39.1 \%$ ).

\section{Differentiation phenotype of HAdV peptide-specific $C D 8^{+} T$ cells}

After in vitro stimulation, A02Hexon ${ }_{\mathrm{TLLY}}{ }^{-}$and A01Penton $_{\mathrm{STDV}^{-}}$-specific $\mathrm{CD}^{+} \mathrm{T}$ cells displayed a phenotype characterized by a loss of CD45RA (Fig. 3b). Phenotypic analysis revealed that the proportion of $\mathrm{CD}^{+}$ T-cell subsets in response to stimulation with A02Hexon $_{\text {TLLY }}$ and A01Penton ${ }_{\text {STDV }}$ significantly changed during T-cell expansion. The highest phenotypic changes were observed in $\mathrm{CD}^{+} \mathrm{T}$-cell responses to A01Penton $_{\text {STDV }}$, with a significant decrease in $\mathrm{T}_{\mathrm{N}}$ (mean $44.1 \%$ to $25.1 \%, \mathrm{p}<0.001$ ) and $\mathrm{T}_{\text {EMRA }}$ (mean $23.9 \%$ to $9.8 \%$, $\mathrm{p}<0.05)$, and significantly increased frequencies of $\mathrm{T}_{\mathrm{CM}}$ (mean $10.8 \%$ to $22.9 \%, \mathrm{p}<0.05$ ) and $\mathrm{T}_{\mathrm{EM}}$ (mean $21.2 \%$ to $42.3 \%, \mathrm{p}<0.01 \%)$. Stimulation with A02Hexon ${ }_{\mathrm{TLLY}}$ also resulted in a significant increase in $\mathrm{CD}^{+} \mathrm{T}_{\mathrm{EM}}$ (mean $24.6 \%$ to $32 \%, \mathrm{p}<0.05 \%)$. Higher frequencies of cytotoxic A02Hexon ${ }_{\text {TLLY}}$-specific (mean 5-fold) and A01Penton $_{\mathrm{STDV}^{-}}$-specific $\mathrm{CD}^{+} \mathrm{T}$ cells (mean 11-fold) were further detected after T-cell expansion using the respective pentamers (Fig. 3b). Expansion of HAdV-specific $\mathrm{CD} 8^{+} \mathrm{T}$ cells in response to the other peptide candidates (Additional file 2: Figure S2B) resulted in a comparable, differentiated phenotype with decreased frequencies of $\mathrm{T}_{\mathrm{N}}$ (mean 1.2-fold) and $\mathrm{T}_{\text {EMRA }}$ (mean 1.7-fold) and increased frequencies of $\mathrm{T}_{\mathrm{CM}}$ (mean 1.5-fold) and $\mathrm{T}_{\mathrm{EM}}$ (mean 1.3-fold).

\section{Cytotoxic capacity of expanded HAdV peptide-specific CD8 ${ }^{+}$ Tcells}

The cytotoxic activity of expanded HAdV-specific CTLs against the six pre-classified immunodominant peptide candidates (Table 1, highlighted in italic) was analyzed to evaluate their functionality and specificity. Comparison of peptide candidates A02Hexon ${ }_{\text {TLLY }}$ and A01Penton ${ }_{\text {STDV }}$ 

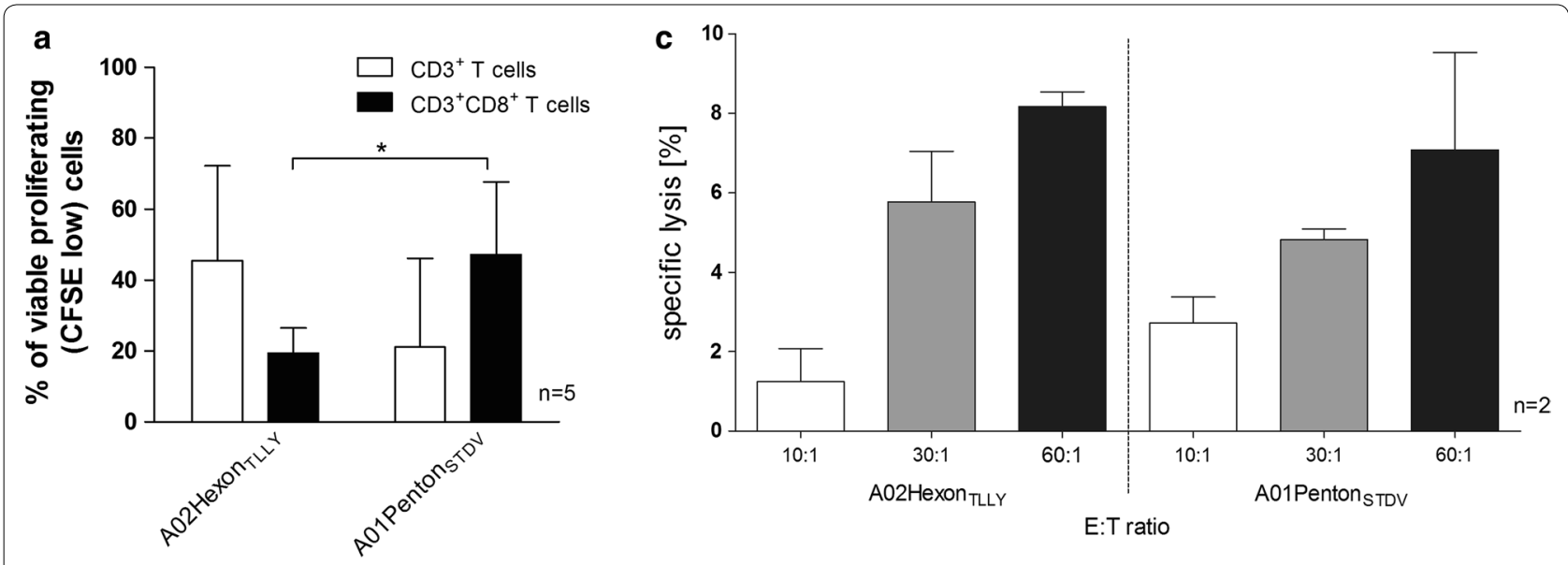

b
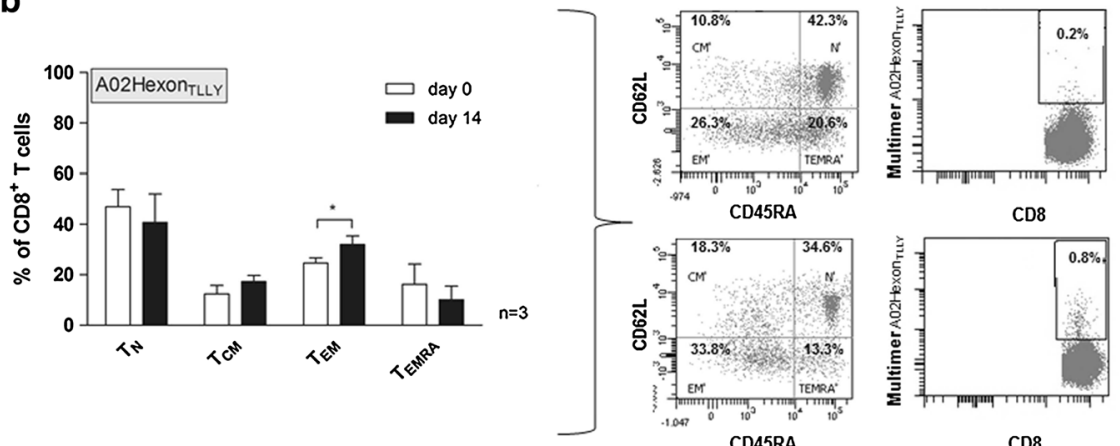

CD45RA

$\operatorname{CD} 8$
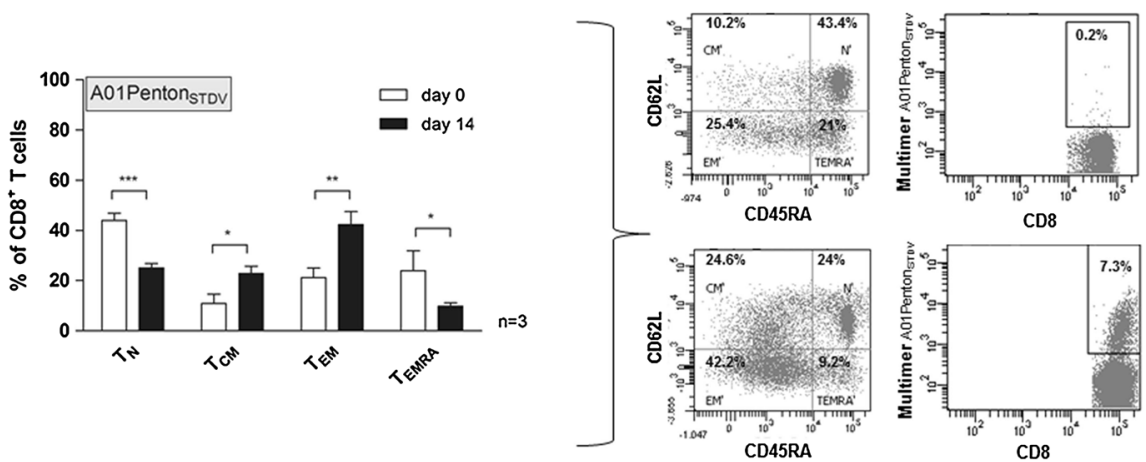

Fig. 3 Analysis of HAdV-specific T-cell responses to the immunodominant epitopes A02Hexon ${ }_{T L L Y}$ and A01Penton STDV $_{\text {in }}$ healthy donors. HAdV-

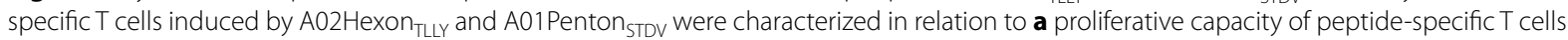
within $\mathrm{CD}^{+}$and $\mathrm{CD} 3^{+} \mathrm{CD} 8^{+} \mathrm{T}$-cell populations $\mathbf{b}$ phenotype and frequency of HAdV-specific CD8 ${ }^{+} \mathrm{T}$ cells, (C) cytotoxicity of CD8 ${ }^{+} \mathrm{T}$ cells by multicolor flow cytometry. a PBMCs from healthy donors were labeled with carboxyfluorescein succinimidyl ester (CFSE) and stimulated over 7 days

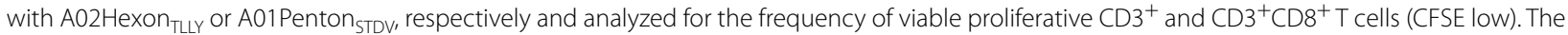
proliferative capacity of unstimulated CSFE-labeled PBMCs (negative control) was subtracted from the values for peptide-stimulated PBMCs. Results of independent experiments $(n=5)$ are expressed as mean \pm SD. b Frequency of A02Hexon TLLY $^{-}$and A01Penton STDV $^{-S_{P}}$-cific CD $8^{+}$T cells and their four subsets - naïve $\left(T_{N}\right)$, central $\left(T_{C M}\right)$, effector memory $\left(T_{E M}\right)$, and terminally differentiated effector memory $\left(T_{E M R A}\right) T$ cells-from healthy donors before (day 0 ) and after two restimulation cycles (day 14), including dot plots for phenotype and multimer ${ }^{+} \mathrm{CD} 8^{+} \mathrm{T}$ cells of one representative donor (upper right). Results of independent experiments $(n=3)$ are expressed as mean \pm SD. c Cytotoxic activity of expanded A02Hexon ${ }_{T L L Y}$ and

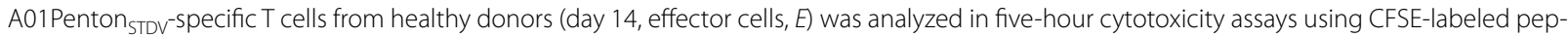
tide-loaded/unloaded PBMCs as target cells (T). Effector T cells were co-cultured with target cells at an E:T ratio of 10:1, 30:10, or 60:1, respectively.

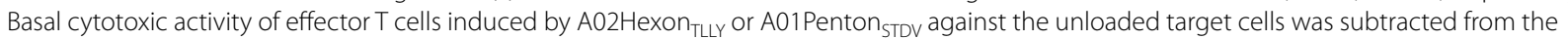
cytotoxic T-cell values against peptide-loaded PBMCs. Results $(n=2)$ are expressed as the mean percentage of target cell lysis \pm SD. Asterisks shown in the figure indicate statistically significant differences between T-cell proliferation, phenotype and cytotoxicity in response to $\mathrm{A} 02 \mathrm{HexOn}_{\mathrm{TLLY}}$ and A01Penton STDV $\left({ }^{*} p<0.05,{ }^{* *} p<0.01,{ }^{* * *} p<0.001\right.$, SD, standard deviation) 
(Fig. 3c) showed that the highest cytotoxicity occurred at an E:T ratio of 60:1 for A02Hexon TLLY $^{\text {-specific CTLs }}$ $(8.2 \pm 0.4 \%)$. The cytotoxic capacities in response to the other candidates (Additional file 2: Figure S2C) were similarly high, while the highest percentage of specific target lysis was detected for B08Hexon ${ }_{\mathrm{DLQD}}$-specific CTLs at an E:T ratio of 60:1 (10.6 $\pm 8.5 \%)$.

Increased expression of IFN- $\gamma$ (cytotoxic marker) and CD107a (degranulation marker) further verified the peptide-specific function and specificity of activated $\mathrm{CD}^{+}$CTLs. A02Hexon $\mathrm{TLLY}_{\text {and A01Penton }}$ STDV generated the highest IFN- $\gamma^{+}$T-cell responses (Fig. 2a), while

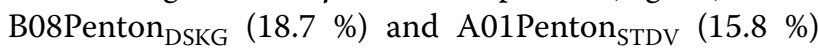
induced the highest frequencies of CD107a-positive $\mathrm{CD}^{+} \mathrm{CD}^{+} \mathrm{T}$ cells (Additional file 2: Figure S2D). Compared to unstimulated $\mathrm{CD}^{+}{ }^{+} \mathrm{CD}^{+}{ }^{+} \mathrm{T}$ cells, the highestfold increases in CD107a-positive $\mathrm{CD}^{+} \mathrm{CD}^{+} \mathrm{T}$ cells was observed in response to the peptides $\mathrm{A} 02 \mathrm{Hex}-$ on $_{\text {TLLY }}$ (5.7-fold increase) and B08Hexon DLQG $_{\text {(3.3-fold }}$ increase).

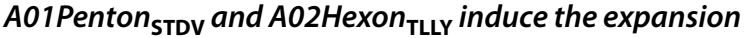 of HAdV-specific CD8 ${ }^{+}$CTLS}

Healthy donors were tested for precursor frequencies of circulating A02Hexon TLLY $^{-}$and A01Penton $_{\text {STDV}^{-} \text {-specific }} \mathrm{CD}^{+} \mathrm{T}$ cells and in vitro $\mathrm{T}$-cell expansion efficiency (Fig. 4a). The frequencies of A02Hexon TLLY $^{-}(0.12 \pm 0.08 \%, \mathrm{p}<0.01)$ and A01Penton $_{\mathrm{STDV}^{-}}(0.11 \pm 0.05 \%, \mathrm{p}<0.001)$ specific CD8 ${ }^{+} \mathrm{T}$-cell precursors in freshly isolated PBMCs were significantly lower than the frequencies of circulating $\mathrm{A} 01 \mathrm{Hexon}_{\mathrm{TDLG}^{-}}$ specific $\mathrm{CD}^{+} \mathrm{T}$ cells $(0.46 \pm 0.48 \%$, positive controls); however, A01Penton ${ }_{\text {STDV }}$ and A01Hexon ${ }_{\text {TDLG }}$ resulted in significant differences after in vitro expansion $(\mathrm{p}<0.05)$. The numbers of responders in freshly isolated PBMCs (A01Hexon $_{\text {TDLG: }}: 66.7 \%$, A02Hexon TLLY 64.3\%, A01Penton $_{\text {STDV: }}$ 63.6 \%) were comparable to those detected by IFN- $\gamma$ EliSpot. After in vitro expansion, significantly higher frequencies of $\mathrm{HAdV}$-specific $\mathrm{CD}^{+} \mathrm{T}$ cells were detected in response to all investigated HAdV peptides; rates ranged from 0.32 to $0.94 \%$, representing a 2.1 to 3.4-fold increase as compared to freshly isolated PBMCs.

Furthermore, the frequencies of antigen-specific $\mathrm{CD} 8^{+}$ $\mathrm{T}$ cells against $\mathrm{A} 02 \mathrm{Hexon}_{\text {TLLY }}$ and A01Penton STDV $_{\text {in }}$ peripheral blood from HAdV-infected patients were monitored to validate their clinical relevance (Fig. 4b). Results obtained by pentamer staining correlated with those from the EliSpot assay. Increased frequencies of HAdV-specific $\mathrm{CD}^{+} \mathrm{T}$ cells against A01Hexon ${ }_{\text {TDLG }}$ (mean $2.46 \%, \mathrm{n}=6$ ), A02Hexon ${ }_{\text {TLLY }}$ (mean $1.64 \%$,

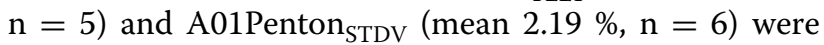
detected with no significant differences between the
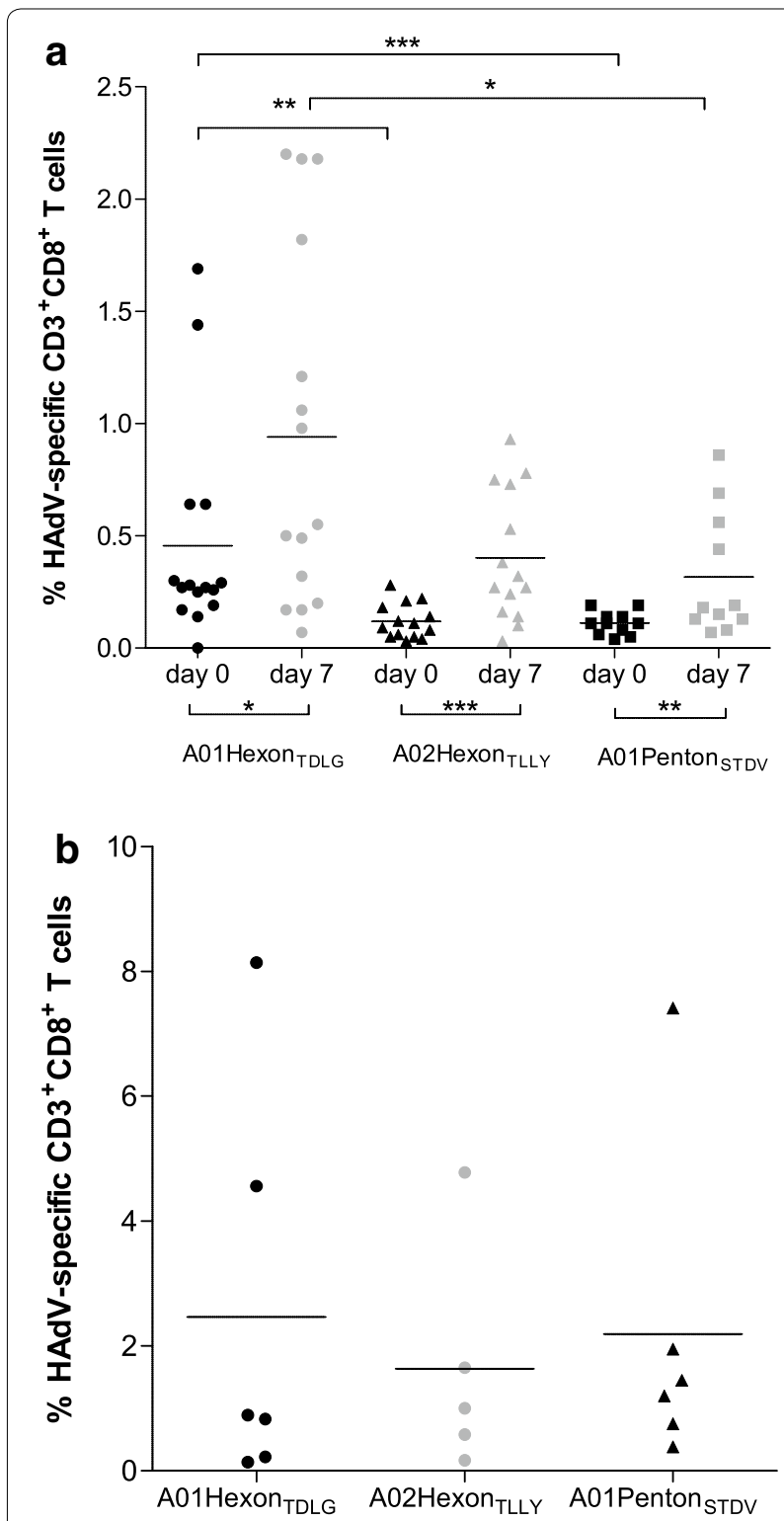

Fig. 4 Frequencies of HAdV-specific T cells in healthy donors and HAdV-infected HSCT recipients. Percentage of HAdV-specific $\mathrm{CD}^{+} \mathrm{CD} 8^{+} \mathrm{T}$ cells as detected by pentamer staining. a PBMCs from healthy donors were analyzed for A01 Hexon TDLG $^{-}, \mathrm{A}_{02} \mathrm{HexO}_{\mathrm{TLLY}^{-}}$ and $\mathrm{A}_{01}$ Penton $_{\mathrm{STDV}^{-}}$-specific $\mathrm{CD}^{+}{ }^{+} \mathrm{CD}^{+} \mathrm{T}$ cells before (day 0 ) and after stimulation with the peptides $\mathrm{A01} \mathrm{HexOn}_{\mathrm{TDLG}}, \mathrm{A02HexOn_{TLLY }}$

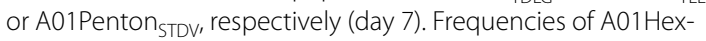

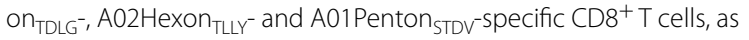
detected by pentamer staining, are expressed as mean frequencies of HAdV-specific $\mathrm{CD}^{+}{ }^{+} \mathrm{CD} 8{ }^{+} \mathrm{T}$ cells. $\mathbf{b}$ T-cell responses were assessed in HAdV-infected patients. Highest frequencies of A01Hexon ${ }_{\text {TDLG }}$

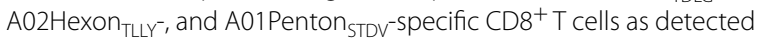
by pentamer staining, were shown for each patient and are expressed as mean frequencies of HAdV-specific $\mathrm{CD}^{+}{ }^{+} \mathrm{CD} 8^{+} \mathrm{T}$ cells. $\mathrm{CD} 8^{+} \mathrm{T}$ cells were stained with PE-labeled pentamers. The results of independent experiments are expressed as mean $\mathrm{HAdV}$-specific $\mathrm{CD}^{+} \mathrm{CD}^{+}$ T-cell frequencies. Asterisks indicate statistically significant differences between the HAdV peptides $\left({ }^{*} p<0.05,{ }^{* *} p<0.01,{ }^{* * *} p<0.001\right.$ ) 
three peptide epitopes. The generated pentamer results emphasize the differentiated CD45RA ${ }^{\text {neg }}$ phenotype of expanded peptide-specific CTLs.

\section{High enrichment efficiency of $\mathrm{A02Hexon}_{\mathrm{TLLY}^{-}}$ and A01Penton STDV $_{\text {-specific T cells }}$}

The function of in vitro expanded HAdV-specific $\mathrm{T}$ cells was evaluated by CSA in order to determine how quickly and strongly HAdV-specific $\mathrm{T}$ cells secreted IFN- $\gamma$ in response to A02Hexon ${ }_{\text {TLLY }}$ and A01PentonSTDV, respectively. IFN- $\gamma^{+}$T-cell populations in healthy donors were investigated by multicolor flow cytometry before and after enrichment (Fig. 5; Additional file 3: Figure S3). According to the peptide-specific $\mathrm{CD}^{+}{ }^{+} \mathrm{T}$-cell frequency in the CSA fraction before enrichment ("Origin"), donors were classified as either weak responders (WR $<0.3 \%$ IFN $-\gamma^{+} \mathrm{CD}^{+}{ }^{+}$T cells, A02Hexon ${ }_{\text {TLLY }}: \mathrm{n}=2$, A01Penton $\left._{\text {STDV }}: \mathrm{n}=3\right)$ or strong responders $(\mathrm{SR},>0.3 \%$ IFN $-\gamma^{+} \mathrm{CD}^{+} \mathrm{T}$ cells, $\mathrm{n}=2$ ). The "Origin" CSA fraction contained $0.21 \pm 0.13 \%$ (WR) and $1.89 \pm 0.78 \%$ (SR) IFN- $\gamma^{+} \mathrm{CD}^{+} \mathrm{T}$ cells, which could be enriched with a mean purity of $12.6 \pm 8.22 \%$ in WR and $76.7 \pm 8.47 \%$ in SR, including $11.0 \pm 12.3 \%$ (WR) to $86.6 \pm 4.59 \%$ (SR) of IFN- $\gamma$ secreting $\mathrm{CD}^{+} \mathrm{CD}^{+} \mathrm{T}$ cells (Fig. 5). The mean frequency of A01Penton STDV $^{- \text {specific }}$ IFN- $\gamma^{+} \mathrm{CD}^{+} \mathrm{T}$ cells before ( $0.17 \pm 0.12 \%$ WR and $0.85 \pm 0.35 \% \mathrm{SR})$ and after enrichment $(3.97 \pm 1.43 \% \mathrm{WR}$ and $54.58 \pm 11.30 \%$ SR) was 1.5-fold lower than for A02Hexon ${ }_{\mathrm{TLLY}}$, whereas the frequency of IFN- $\gamma^{+} \mathrm{CD}^{+} \mathrm{CD} 8^{+} \mathrm{T}$ cells was comparable $(2.60 \pm 0.62 \% \mathrm{WR}$ and $90.78 \pm 2.67 \% \mathrm{SR})$ to

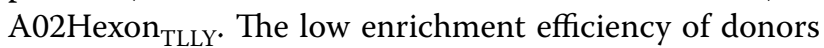
classified as weak responders reflects the low precursor frequency of antigen-specific CTLs (A02Hexon TLLY: $_{\text {: }}$ $0.19 \%$, A01Penton STDV: $0.30 \%$ ), as determined by pentamer staining, which may lead to a low binding affinity of IFN- $\gamma$-secreting $\mathrm{T}$ cells in the CSA. In this context, starting with an antigen-specific $\mathrm{CD} 8^{+} \mathrm{T}$-cell frequency $>0.3 \%$ (A02Hexon $_{\text {TLLY: }} 0.82 \%$, A01Penton ${ }_{\text {STDV }}: 5.37 \%$, $\mathrm{SR})$ resulted in the enrichment of highly pure IFN- $\gamma-$ secreting $\mathrm{T}$ cells.

\section{Discussion}

Adoptive T-cell immunotherapy has become a promising treatment option for patients with adenoviral infections after transplantation since these cells were shown to play a pivotal role in viral control and clearance. Accurate monitoring of the viral load and antiviral T-cell immunity is of great importance to effectively treat emerging or overt HAdV infections in post-transplant patients. Moreover, analysis of the specific T-cell repertoire in potential T-cell donors is essential to identify the most suitable donors for adoptive transfer and may prove helpful for donor choice in patients with pre-transplant viral conditions.

In this study, we assessed the immunogenicity of 19 potential adenoviral CTL epitopes identified by reverse immunology. Various epitope prediction algorithms were employed to pre-screen for immunodominant CTL epitopes. We found that the prediction accuracy for $\mathrm{CD}^{+}$T-cell epitopes was improved by combining different algorithms for peptide binding affinity and pMHC complex stability. Because prediction results do not reflect one-to-one correlation with experimental data, we validated the immunogenicity of the predicted epitopes in vitro. IFN- $\gamma$ EliSpot evaluation of peptidespecific T-cell responses in PBMCs from healthy donors resulted in the pre-classification of four CTL epitopes as low immunodominant (response $\geq 20 \%$ ) and two as high immunodominant (response $\geq 50 \%$ ) (Table 1, highlighted in italic). Immunodominance of these six candidates was verified by T-cell immunoassays and T-cell immunomonitoring in HAdV-infected HSCT patients, which delineated the significance of the identified $\mathrm{CD}^{+}$ T-cell epitopes in vivo. Guenther et al. identified the naturally presented HAdV epitopes LTDLGQNLLY and VPATGRTLVL [19], for which we obtained high prediction scores. These results underline the high prediction accuracy of HLA-class I epitopes obtained by the allelespecific prediction algorithms utilized in the present study.

\section{Description of the first identified penton-derived immunodominant $\mathrm{CD}^{+} \mathrm{T}$-cell epitopes}

Here, we were focused on the identification of peptide epitopes from HAdV penton, a major capsid protein. The penton base interacts with the other major capsid proteins (hexon and fiber) and is known to be involved in adenovirus cell entry [38]. Despite the variability of clinically relevant HAdV types, the penton sequence is composed of highly conserved regions and short hypervariable loops, similar to hexon [39].

Identification of immunodominant T-cell epitopes from these conserved regions represents an attractive approach to induce antiviral $\mathrm{T}$ cells that are cross-reactive with several potentially lethal HAdV types. Previous studies have demonstrated sequential or concomitant coinfections with different HAdV types in immunocompromised patients, which seem to result in the generation of recombinant HAdV types $[6,40,41]$. In the present and a previous study we identified HAdV types 1,2 , and 31 as the predominant pathogens in most pediatric patients with severe HAdV disease [7]. In our present study, 10 of 26 post-transplant patients were infected with type 31 of HAdV species A, and three of them were co-infected 
Enrichment of activated A02Hexon $_{\text {TLLY }}$-specific T cells

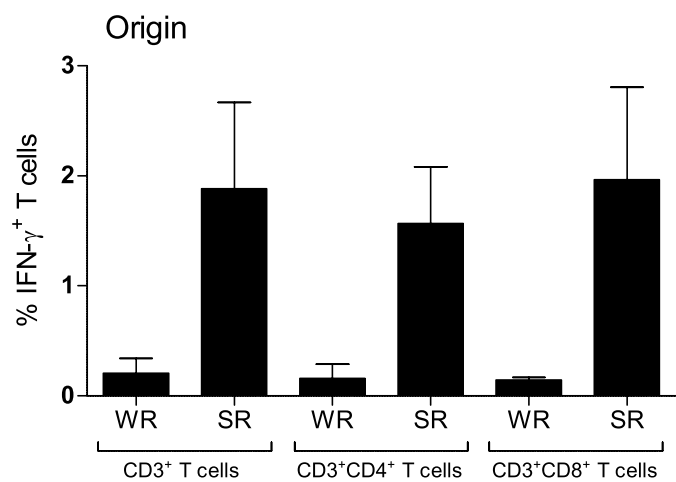

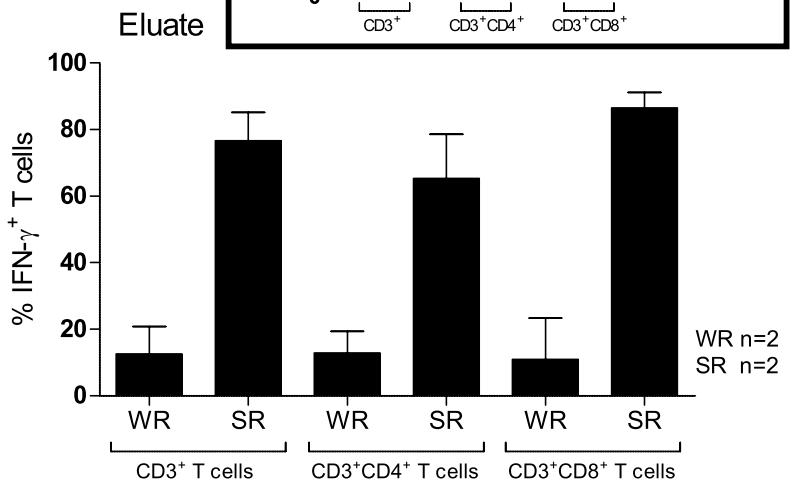

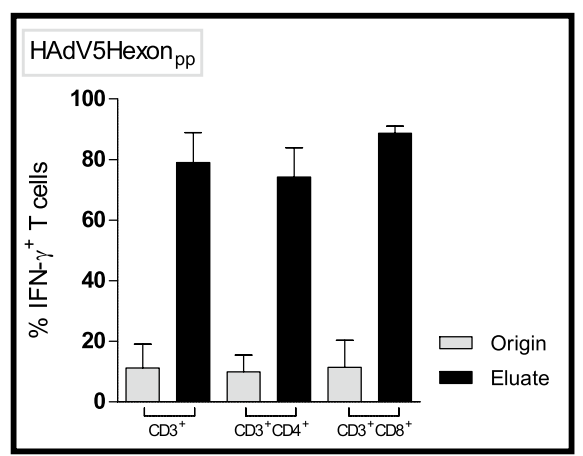

Eluate

Enrichment of activated

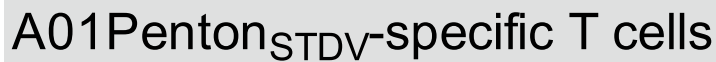
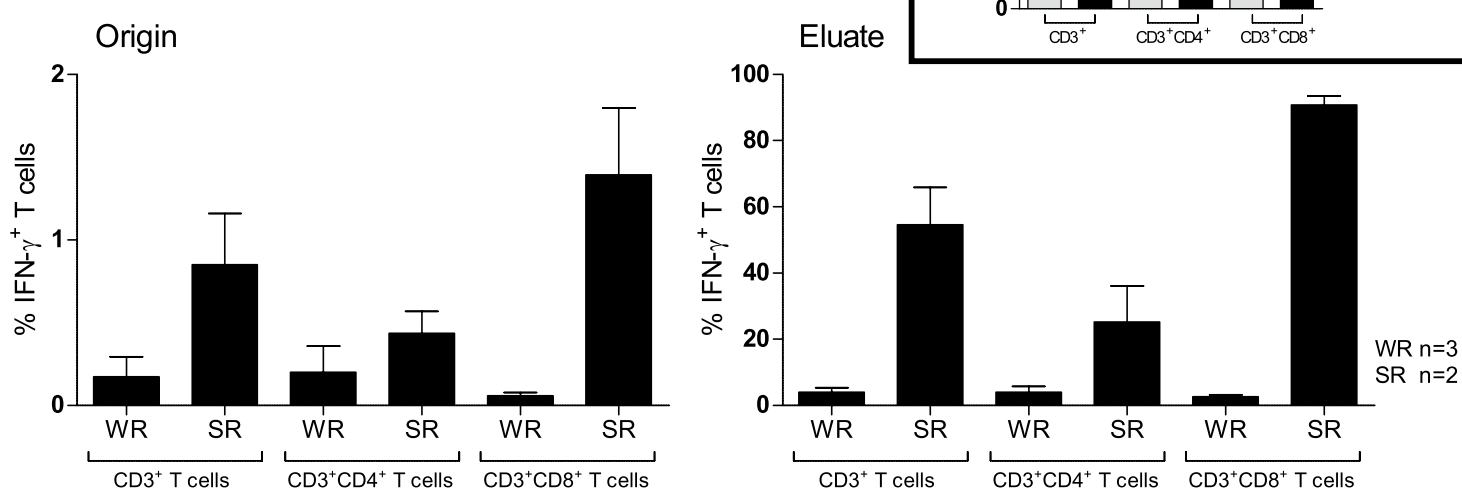

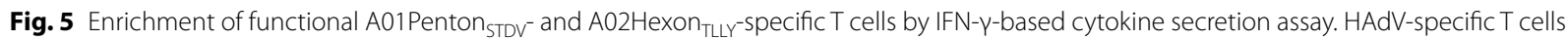
were induced by stimulating PBMCs from healthy donors with A02Hexon ${ }_{T L L Y}, A_{01}$ Penton $_{S T D V}, H_{A d V} H_{\text {Hexon }}$ or or HAdV5Penton $_{\mathrm{pp}}$, respectively. Stimulated T cells were isolated using IFN- - -based cytokine secretion assay. The frequency of IFN- $\gamma$-secreting cells among $\mathrm{CD} 3^{+}, \mathrm{CD}^{+} \mathrm{CD} 4^{+}$and $\mathrm{CD}^{+} \mathrm{CD}^{+} \mathrm{T}$ cells in the CSA fractions before ("Origin") and after ("Eluate") enrichment were determined by multicolor flow cytometry. The results of the peptide-specific T-cells enrichment process for weak responders (WR, $<0.3 \% \mathrm{IFN}-\gamma^{+} \mathrm{CD}^{+} \mathrm{T}$ cells) and strong responders (SR, $>0.3 \%$ IFN$\mathrm{Y}^{+} \mathrm{CD}^{+} \mathrm{T}$ cells) are shown as mean \pm standard deviation (SD) 
with type 2 of HAdV species C. The peptide epitopes identified in this study are shared among HAdV types and may thus facilitate viral clearance even in patients suffering from co-infection with different strains.

For the first time we identified three low immunodomi-

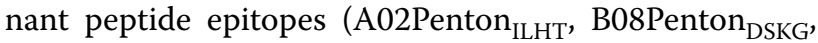
B08Penton ${ }_{\text {DSKK }}$ ) and one high immunodominant peptide epitope (A01Penton STDV $_{\text {) }}$ ) the major HAdV capsid protein penton. Sequences of all identified immunodominant epitopes were highly conserved among the clinically relevant HAdV species $C$, with the exception of A31-derived B08Penton $_{\text {DSKG }}$ (DSKGRSYNL), which only differs in one amino acid from the peptide B08Penton ${ }_{\text {DSKK }}$ (DSKKRSYNL) but is composed of the same amino acids at the conserved anchor positions P2 and P9. The sequence of the newly identified A01Penton STDV $_{\text {is located between }}$ amino acid positions 76 and 84 of the penton protein of HAdV types 1, 2, and 5. Immune responses to the whole adenovirus, including the hexon protein, were dominated by memory $\mathrm{CD} 4^{+} \mathrm{T}$ cells. Interestingly, A01Penton ${ }_{\text {STDV }}$ was identified as a strong inducer of functional $\mathrm{CD}^{+}$ CTLs (11-fold increase in A01Penton STDV$^{-}$-specific CD8 ${ }^{+}$ CTLs), which could be efficiently enriched to a high frequency (90.4\% recovery), comparable to the HAdV5Penton $_{\mathrm{pp}}$ peptide pool (96.9\% recovery). In vitro expanded A01Penton $_{\mathrm{STDV}^{-} \text {-specific }} \mathrm{CD}^{+} \mathrm{T}$ cells showed a differentiated CD45RA ${ }^{\text {neg }}$ T-cell phenotype, with $\mathrm{T}_{\mathrm{EM}}$ proved to be essential for effective clearance of and protection against HAdV infections, while $\mathrm{T}_{C M}$ demonstrated to be involved in preventive long-term immunity [13]. The immunogenicity of all four pre-classified immunodominant penton epitopes was verified by antiviral T-cell monitoring and in vitro T-cell immunoassay in healthy donors and patients.

\section{Evaluation of hexon-specific T-cell responses induced by the predicted CTL epitopes}

In healthy donors, coordinate responses of hexon-specific $\mathrm{CD}^{+}{ }^{+}$and $\mathrm{CD} 8^{+} \mathrm{T}$ cells were demonstrated to contribute to the control of HAdV infections, which persist as memory $\mathrm{T}$ cells [21]. Most hexon-derived epitopes are CD4 restricted [20, 22, 23]. We aimed to identify novel hexon-derived $\mathrm{CD} 8^{+}$T-cell epitopes by evaluating the immunogenic potential of six predicted $\mathrm{CD}^{+}$T-cell epitopes. Overall, we detected HAdV-specific T-cell responses to $3 / 6$ predicted peptide candidates in healthy donors. B08Hexon ${ }_{\text {DLQD }}$ was thus pre-classified as a low immunodominant ( $\geq 20 \%$ response) and $\mathrm{A} 02 \mathrm{Hexon}_{\mathrm{TLLY}}$ $[13,22,23]$ as a high immunodominant CTL epitope ( $\geq 50 \%$ response). The immunogenicity of both candidates was verified by $\mathrm{T}$-cell monitoring and in vitro $\mathrm{T}$-cell immunoassay. In accordance to already published data (Table 1), we found no or only minimal $\mathrm{T}$-cell responses to the peptide candidates A01Hexon ${ }_{\mathrm{TNDQ}}$ [21], A02Hexon $_{\text {TLAV }}$ [13], and B08Hexon ${ }_{\text {GLRY }}$ [20]. In vitro expanded functional A02Hexon TLLY $^{-}$specific CTLs showed a high proliferative and cytotoxic capacity and displayed a CD45RA $^{\text {neg }}$ differentiated phenotype, which could be efficiently enriched to a significantly high frequency (85\% recovery), comparable to the HAdV5Hexon ${ }_{\mathrm{pp}}$ peptide pool ( $95.5 \%$ recovery).

Olive et al. demonstrated that additional three residues at each end of the immunodominant peptide Hexon $_{\text {TLLY }}$ (15-mer peptide) resulted in a stronger $\mathrm{CD}_{4}^{+}$ T-cell response. In addition, a lower peptide concentration for in vitro T-cell activation was required compared to the nonamer, indicating that the 15 -mer peptide is an optimal CD4 ${ }^{+}$T-cell epitope $[22,23]$. Guether et al. identified the decamer of the known immunodominant HLAA01-restricted hexon-derived peptide (A01Hexon ${ }_{\mathrm{TDLG}}$, LTDLGQNLLY) as a naturally presented T-cell epitope that induces peptide-specific $\mathrm{T}$ cells with a higher proliferative, cytotoxic, and IFN- $\gamma$-producing capacity than T cells specific for the shorter peptide TDLGQNLLY [19]. Therefore, we will evaluate the immunogenic potential of longer peptides from the novel identified low immunodominant $\mathrm{B} 8 \mathrm{Hexon}_{\mathrm{DLQD}}$ peptide in a future study.

\section{Comparison of HAdV-specific T-cell repertoires in healthy donors and HSCT recipients}

Clinical relevance of the identified high immunodominant CTL epitopes A02Hexon ${ }_{\text {TLLY }}$ and A01Peton ${ }_{\text {STDV }}$ was further assessed in HAdV-infected HSCT recipients, compared to healthy donors and correlated to T-cell responses induced by HAdV5Hexon ${ }_{\mathrm{pp}}$, HAdV5Penton $_{\mathrm{pp}}$, and the immunodominant A01Hexon ${ }_{\text {TDLG }}$. As expected, the majority of donors and patients had HAdV-specific $\mathrm{T}$ cells against hexon and penton, and the frequency of hexon-specific $\mathrm{T}$ cells was higher than that of pentonspecific $\mathrm{T}$ cells in both cohorts. More than $50 \%$ of all tested donors and patients had HAdV-specific $\mathrm{T}$ cells against $\mathrm{A} 02 \mathrm{Hexon}_{\mathrm{TLLY}}$, but at an up to 2.2 (donors) to ninefold (patients) lower frequency than the investigated control antigens HAdV5Hexon pp $_{\text {and }}$ A01Hexon ${ }_{\text {TDLG. }}$. For this reason, A02Hexon ${ }_{\text {TLLY }}$ can be classified as a high immunodominant CTL epitope but, as mentioned before, it has a lower immunogenic potential compared to the known HAdV5Hexon ${ }_{\mathrm{pp}}$ and A01Hexon ${ }_{\mathrm{TDLG}}$, as underlined by the higher immunogenicity of the 15-mer peptide DEPTLLYVLFEVFDV [22]. Interestingly, the immunogenic potential of A01Penton ${ }_{\text {STDV }}$, the novel penton-derived CTL epitope, was comparable to that of HAdV5Penton $_{\mathrm{pp}}$ in healthy donors and patients. This finding indicates that A01Penton ${ }_{\text {STDV }}$ is a major immunodominant penton-derived CTL epitope. In infected HSCT recipients we detected higher T-cell responses to 
the A01Penton ${ }_{\text {STDV }}$ than to the hexon-derived A02Hexon $_{\text {TLLY }}$, which was the reverse in healthy donors. These data indicate that penton-specific $\mathrm{T}$ cells might be essential for viral control. Future studies including monitoring of T-cell functionality and specificity should be done to get more inside into the interplay between hexon- and penton-specific $\mathrm{T}$ cells in the first line of defense and/or long-term protective immunity against HAdV.

\section{Peptide-specific T-cell precursor frequencies and limits of detection}

Low frequencies of circulating HAdV-specific T-cell precursors in peripheral blood make it difficult to detect HAdV-specific $T$ cells, which can lead to false-negative results [36]. We were able to detect specific T-cell responses to the peptide epitopes $\mathrm{A} 02 \mathrm{Hexon}_{\mathrm{TLLY}}$ and A01Penton $_{\text {STDV }}$ directly in freshly isolated PBMCs from healthy donors by IFN- $\gamma$ EliSpot, albeit at quite low frequencies $\left(\mathrm{A}^{2} \mathrm{Hexon}_{\mathrm{TLLY}}: 17 \mathrm{spw}, \mathrm{A} 01\right.$ Penton $_{\text {STDV }}: 10$ spw). Interestingly, the number of responders after peptide-restimulation was unchanged, indicating that no false-negative results were obtained in freshly isolated PBMCs compared to peptide-restimulated cells and that all tested donors were correctly identified as responders and non-responders. However, evaluation of A02Hexon $_{\text {TLLY }}$ and A01Penton ${ }_{\text {STDV }}$ by pMHC multimer staining indicates the need for antigen-dependent $\mathrm{T}$-cell expansion to avoid overlooking effector function of peptideinduced CTLs with very low precursor frequencies. Pentamer staining of freshly isolated PBMCs yielded

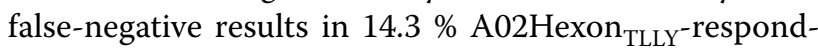
ers and $9.1 \%$ of A02Penton ${ }_{\mathrm{STD}^{-}}$-responders. Pentamer staining with in vitro stimulated cells resulted in more accurate identification of positive responders as a clearly defined peptide-specific $\mathrm{CD} 8^{+} \mathrm{T}$-cell population with up to 3.3-fold higher frequencies. In this context, the highly sensitive IFN- $\gamma$ EliSpot assay is a suitable technology for the detection of low precursor frequencies of circulating HAdV-specific $\mathrm{T}$ cells in peripheral blood. Conversely, for unambiguous identification of responders and nonresponders by pentamer staining, we recommend short in vitro stimulation. The enrichment efficiency of antigen-specific $\mathrm{T}$ cells via CSA was further affected by the percentage of HAdV-specific $\mathrm{T}$ cells. The enrichment efficiency of A02Hexon TLLY $^{-}$and A02Hexon TLLY $^{-}$specific $\mathrm{CD}^{+} \mathrm{T}$ cells was lower (purity $<13 \%$ ) when the starting frequency was $<0.3 \%$, whereas a high enrichment efficiency was obtained by using starting frequencies $>0.3 \%$ (<67\% purity). Therefore, short-term expansion protocols for the generation of higher numbers of functionally active HAdV-specific T cells, as described by Geyeregger et al., are a suitable option to generate sufficient numbers of HAdV-specific $\mathrm{T}$ cells for adoptive immunotherapy
[12, 13]. In addition, manufacturing of clinical-grade

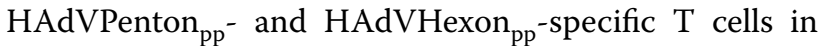
combination might be a promising option to provide sufficient numbers of effective HAdV-specific $\mathrm{T}$ cells for the adoptive T-cell transfer in immunocompromised patients.

\section{Conclusions}

In summary, HAdV-specific T-cell responses to novel identified immunodominant CTL epitopes were observed in healthy donors, and the in vivo relevance of these identified CTL epitopes, as predicted by computer algorithms, was confirmed in HAdV-infected patients.

We describe the first immunodominant adenovirus $\mathrm{CD}^{+}$T-cell epitopes from the penton, of which A01Penton $_{\text {STDV }}$ could be classified as the first high immunodominant CTL epitope discovered to date. HAdV-specific T-cell responses to A01Penton ${ }_{\text {STDV }}$ were comparable to those to the HAdV5Penton ${ }_{p p}$ overlapping peptide pool. The development of penton-specific T-cell immunity in HAdV-infected HSCT recipients suggested that, as an immunological target, the penton protein is not secondary to the hexon protein. Penton-specific T cells, particularly $\mathrm{CD}^{+}$CTLs, seem to be essential for effective defense against HAdV. Immunogenicity of the CTL epitope A02Hexon ${ }_{\text {TLLY }}$ was verified according to its prevalence in healthy donors and patients. A broad repertoire of immunodominant $\mathrm{CD}^{+}$and $\mathrm{CD}^{+}$T-cell epitopes appears to be crucial for improved immunomonitoring by means of precise quantitative assessment. This improvement will enhance the efficacy of adoptive immunotherapy by enabling the timely start of the adoptive transfer with the most suitable HAdV-specific T-cell populations.

\section{Additional files}

Additional file 1: Figure S1. Validation of peptide-binding affinity and concentration.

Additional file 2: Figure S2. Analysis of HAdV-specific T-cell responses against the novel immunodominant T-cell epitope in healthy donors.

Additional file 3: Figure S3. Enrichment of functional $\mathrm{AO}_{2 \mathrm{HexO}} \mathrm{TLLY}_{\mathrm{Y}}$ and A01Penton $_{\text {STDV }}$ - specific T cells by IFN- $\gamma$-based cytokine secretion assay.

\section{Authors' contributions}

ST helped to design the study, performed the epitope prediction analysis, carried out the T-cell screening and stimulation experiments and functional assays, performed data collection and statistical analysis, and wrote the manuscript. RG contributed helpful and critical discussions and helped to draft the manuscript. JK participated in T-cell donor screening, contributed helpful discussions, and helped to draft the manuscript. AH performed human adenovirus typing, contributed helpful and critical discussions, and helped to draft the manuscript. CF contributed helpful and critical discussions and helped to draft the manuscript. RB contributed helpful and critical discussions, helped to draft the manuscript, and approved the final version of the manuscript for publication. BMK provided blood samples from HSCT 
recipients during HAdV infection, contributed helpful and critical discussions about clinical background issues, and helped to draft the manuscript. BEV conceived the study, participated in its design and coordination, designed the T-cell stimulation assays, immunoassays, and data analysis procedures, and cowrote the manuscript. The last two authors (BMK and BEV) jointly contributed equally to the conception and preparation of the manuscript. All authors read and approved the final manuscript.

\begin{abstract}
Author details
1 Institute for Transfusion Medicine, Hannover Medical School, Carl-Neuberg-Strasse 1, 30625 Hannover, Germany. ${ }^{2}$ Integrated Research and Treatment Center (IFB-Tx), Hannover Medical School, Carl-Neuberg-Strasse 1, 30625 Hannover, Germany. ${ }^{3}$ St. Anna Kinderkrebsforschung e.V., Children's Cancer Research Institute, Vienna, Austria. ${ }^{4}$ Institute for Virology, Hannover Medical School, Carl-Neuberg-Strasse 1, 30625 Hannover, Germany. ${ }^{5}$ Department of Paediatric Haematology and Oncology, Hannover Medical School, Carl-Neuberg-Strasse 1, 30625 Hannover, Germany.
\end{abstract}

\section{Acknowledgements}

The authors would like to thank Dörthe Rokitta, Marina Kramer, Sarina Lukis, Nicole Neumann, and Christopher Mielke for their excellent technical assistance. This study was supported by a grants from the German Children's Cancer Research Fund (Deutsche Kinderkrebshilfe), the German Federal Ministry of Education and Research (reference number: 01EO0802, 01EO1302), and a start-up grant from Hannover Medical School (internal university research funding, HiLF).

\section{Competing interests}

The authors declare that they have no competing interests.

Received: 27 January 2016 Accepted: 26 September 2016 Published online: 07 October 2016

\section{References}

1. Englund J, Feuchtinger T, Ljungman P. Viral infections in immunocompromised patients. Biol Blood Marrow Transplant. 2011;17:S2-5.

2. Feucht J, Opherk K, Lang P, Kayser S, Hartl L, Bethge W, Matthes-Martin S, Bader P, Albert MH, Maecker-Kolhoff B, et al. Adoptive T-cell therapy with hexon-specific Th1 cells as a treatment of refractory adenovirus infection after HSCT. Blood. 2015;125:1986-94.

3. George D, El-Mallawany NK, Jin Z, Geyer M, Della-Latta P, Satwani P, Garvin $\mathrm{JH}$, Bradley MB, Bhatia M, van de Ven C, et al. Adenovirus infection in paediatric allogeneic stem cell transplantation recipients is a major independent factor for significantly increasing the risk of treatment related mortality. Br J Haematol. 2012;156:99-108.

4. Wy Ip W, Qasim W. Management of adenovirus in children after allogeneic hematopoietic stem cell transplantation. Adv Hematol. 2013;2013:176418.

5. Ganzenmueller T, Heim A. Adenoviral load diagnostics by quantitative polymerase chain reaction: techniques and application. Rev Med Virol. 2012;22:194-208.

6. Lion T. Adenovirus infections in immunocompetent and immunocompromised patients. Clin Microbiol Rev. 2014;27:441-62.

7. Mynarek M, Ganzenmueller T, Mueller-Heine A, Mielke C, Gonnermann A, Beier R, Sauer M, Eiz-Vesper B, Kohstall U, Sykora KW, et al. Patient, virus, and treatment-related risk factors in pediatric adenovirus infection after stem cell transplantation: results of a routine monitoring program. Biol Blood Marrow Transplant. 2014;20:250-6.

8. Feuchtinger T, Lucke J, Hamprecht K, Richard C, Handgretinger R, Schumm M, Greil J, Bock T, Niethammer D, Lang P. Detection of adenovirus-specific $T$ cells in children with adenovirus infection after allogeneic stem cell transplantation. Br J Haematol. 2005;128:503-9.

9. Chatziandreou I, Gilmour KC, MCNicol AM, Costabile M, Sinclair J, Cubitt D, Campbell JD, Kinnon C, Qasim W, Gaspar HB. Capture and generation of adenovirus specific $\mathrm{T}$ cells for adoptive immunotherapy. Br J Haematol. 2007;136:117-26.

10. Feuchtinger T, Matthes-Martin S, Richard C, Lion T, Fuhrer M, Hamprecht K, Handgretinger R, Peters C, Schuster FR, Beck R, et al. Safe adoptive transfer of virus-specific T-cell immunity for the treatment of systemic adenovirus infection after allogeneic stem cell transplantation. $\mathrm{Br} J$ Haematol. 2006;134:64-76

11. Feuchtinger T, Richard C, Joachim S, Scheible MH, Schumm M, Hamprecht K, Martin D, Jahn G, Handgretinger R, Lang P. Clinical grade generation of hexon-specific T cells for adoptive T-cell transfer as a treatment of adenovirus infection after allogeneic stem cell transplantation. J Immunother. 2008;31:199-206.

12. Geyeregger R, Freimuller $C$, Stemberger J, Artwohl M, Witt $V$, Lion T, Fischer G, Lawitschka A, Ritter J, Hummel M, et al. First-in-man clinical results with good manufacturing practice (GMP)-compliant polypeptideexpanded adenovirus-specific T cells after haploidentical hematopoietic stem cell transplantation. J Immunother. 2014;37:245-9.

13. Geyeregger R, Freimuller C, Stevanovic S, Stemberger J, Mester G, Dmytrus J, Lion T, Rammensee HG, Fischer G, Eiz-Vesper B, et al. Shortterm in vitro expansion improves monitoring and allows affordable generation of virus-specific T-cells against several viruses for a broad clinical application. PLoS ONE. 2013;8:e59592.

14. Lion T, Baumgartinger R, Watzinger F, Matthes-Martin S, Suda M, Preuner S, Futterknecht B, Lawitschka A, Peters C, Potschger U, Gadner H. Molecular monitoring of adenovirus in peripheral blood after allogeneic bone marrow transplantation permits early diagnosis of disseminated disease. Blood. 2003;102:1114-20.

15. Lion T, Kosulin K, Landlinger C, Rauch M, Preuner S, Jugovic D, Potschger U, Lawitschka A, Peters C, Fritsch G, Matthes-Martin S. Monitoring of adenovirus load in stool by real-time PCR permits early detection of impending invasive infection in patients after allogeneic stem cell transplantation. Leukemia. 2010;24:706-14.

16. Hage E, Gerd Liebert U, Bergs S, Ganzenmueller T, Heim A. Human mastadenovirus type 70: a novel, multiple recombinant species D mastadenovirus isolated from diarrhoeal faeces of a haematopoietic stem cell transplantation recipient. J Gen Virol. 2015;96:2734-42.

17. Toth K, Ying B, Tollefson AE, Spencer JF, Balakrishnan L, Sagartz JE, Buller RM, Wold WS. Valganciclovir inhibits human adenovirus replication and pathology in permissive immunosuppressed female and male Syrian hamsters. Viruses. 2015;7:1409-28.

18. Ganzenmueller T, Buchholz S, Harste G, Dammann E, Trenschel R, Heim A. High lethality of human adenovirus disease in adult allogeneic stem cell transplant recipients with high adenoviral blood load. J Clin Virol. 2011:52:55-9.

19. Gunther PS, Peper JK, Faist B, Kayser S, Hartl L, Feuchtinger T, Jahn G, Neuenhahn M, Busch DH, Stevanovic S, Dennehy KM. Identification of a novel immunodominant HLA-B*07: 02-restricted adenoviral peptide epitope and its potential in adoptive transfer immunotherapy. J Immunother. 2015;38:267-75.

20. Leen AM, Christin A, Khalil M, Weiss H, Gee AP, Brenner MK, Heslop HE Rooney CM, Bollard CM. Identification of hexon-specific CD4 and CD8 T-cell epitopes for vaccine and immunotherapy. J Virol. 2008;82:546-54.

21. Leen AM, Sili U, Vanin EF, Jewell AM, Xie W, Vignali D, Piedra PA, Brenner MK, Rooney CM. Conserved CTL epitopes on the adenovirus hexon protein expand subgroup cross-reactive and subgroup-specific $C D 8^{+} \mathrm{T}$ cells. Blood. 2004;104:2432-40.

22. Olive M, Eisenlohr L, Flomenberg N, Hsu S, Flomenberg P. The adenovirus capsid protein hexon contains a highly conserved human $\mathrm{CD}^{+} \mathrm{T}$-cell epitope. Hum Gene Ther. 2002;13:1167-78.

23. Tang J, Olive M, Champagne K, Flomenberg N, Eisenlohr L, Hsu S, Flomenberg P. Adenovirus hexon T-cell epitope is recognized by most adults and is restricted by HLA DP4, the most common class II allele. Gene Ther. 2004;11:1408-15.

24. Zandvliet ML, Falkenburg JH, van Liempt E, Veltrop-Duits LA, Lankester AC, Kalpoe JS, Kester MG, van der Steen DM, van Tol MJ, Willemze R, et al. Combined $\mathrm{CD}^{+}$and $\mathrm{CD}^{+}{ }^{+}$adenovirus hexon-specific $T$ cells associated with viral clearance after stem cell transplantation as treatment for adenovirus infection. Haematologica. 2010;95:1943-51.

25. Sukdolak C, Tischer S, Dieks D, Figueiredo C, Goudeva L, Heuft HG, Verboom M, Immenschuh S, Heim A, Borchers S, et al. CMV-, EBV- and ADV-specific T cell immunity: screening and monitoring of potential third-party donors to improve post-transplantation outcome. Biol Blood Marrow Transplant. 2013;19:1480-92.

26. Kessler JH, Melief CJ. Identification of T-cell epitopes for cancer immunotherapy. Leukemia. 2007;21:1859-74. 
27. Figueredo J, Limberis MP, Wilson JM. Prediction of cellular immune responses against CFTR in patients with cystic fibrosis after gene therapy. Am J Respir Cell Mol Biol. 2007;36:529-33.

28. Nussbaum AK, Kuttler C, Tenzer S, Schild H. Using the world wide web for predicting CTL epitopes. Curr Opin Immunol. 2003;15:69-74.

29. Rammensee H, Bachmann J, Emmerich NP, Bachor OA, Stevanovic S. SYFPEITHI: database for MHC ligands and peptide motifs. Immunogenetics. 1999;50:213-9.

30. Parker KC, Bednarek MA, Coligan JE. Scheme for ranking potential HLA-A2 binding peptides based on independent binding of individual peptide side-chains. J Immunol. 1994;152:163-75.

31. Calis JJ, Reinink P, Keller C, Kloetzel PM, Kesmir C. Role of peptide processing predictions in T cell epitope identification: contribution of different prediction programs. Immunogenetics. 2015;67:85-93.

32. Verboom M, Hallensleben M, Horn PA, Blasczyk R. Bioinformatic integration of biomechanics makes HLA sequencing universally applicable. Tissue Antigens. 2007;70:338-9.

33. Jorgensen KW, Rasmussen M, Buus S, Nielsen M. NetMHCstab-predicting stability of peptide-MHC-I complexes; impacts for cytotoxic T Iymphocyte epitope discovery. Immunology. 2014;141:18-26.

34. Zirlik KM, Zahrieh D, Neuberg D, Gribben JG. Cytotoxic T cells generated against heteroclitic peptides kill primary tumor cells independent of the binding affinity of the native tumor antigen peptide. Blood 2006;108:3865-70.

35. Boyle LH, Goodall JC, Gaston JS. Major histocompatibility complex class I-restricted alloreactive CD4 ${ }^{+}$T cells. Immunology. 2004;112:54-63.
36. Tischer S, Dieks D, Sukdolak C, Bunse C, Figueiredo C, Immenschuh S, Borchers S, Stripecke R, Maecker-Kolhoff B, Blasczyk R, Eiz-Vesper B. Evaluation of suitable target antigens and immunoassays for high-accuracy immune monitoring of cytomegalovirus and Epstein-Barr virus-specific T cells as targets of interest in immunotherapeutic approaches. J Immunol Methods. 2014;408:101-13.

37. Harndahl M, Rasmussen M, Roder G, Dalgaard Pedersen I, Sorensen M Nielsen M, Buus S. Peptide-MHC class I stability is a better predictor than peptide affinity of CTL immunogenicity. Eur J Immunol. 2012;42:1405-16.

38. Madisch I, Hofmayer S, Moritz C, Grintzalis A, Hainmueller J, Pring-Akerblom P, Heim A. Phylogenetic analysis and structural predictions of human adenovirus penton proteins as a basis for tissue-specific adenovirus vector design. J Virol. 2007:81:8270-81.

39. Zubieta C, Schoehn G, Chroboczek J, Cusack S. The structure of the human adenovirus 2 penton. Mol Cell. 2005;17:121-35.

40. Gray GC, McCarthy T, Lebeck MG, Schnurr DP, Russell KL, Kajon AE, Landry ML, Leland DS, Storch GA, Ginocchio CC, et al. Genotype prevalence and risk factors for severe clinical adenovirus infection, United States 2004-2006. Clin Infect Dis. 2007;45:1120-31.

41. Takayama R, Hatakeyama N, Suzuki N, Yamamoto M, Hayashi T, Ikeda Y, Ikeda H, Nagano H, Ishida T, Tsutsumi H. Quantification of adenovirus species $B$ and $C$ viremia by real-time PCR in adults and children undergoing stem cell transplantation. J Med Virol. 2007;79:278-84.

\section{Submit your next manuscript to BioMed Central and we will help you at every step:}

- We accept pre-submission inquiries

- Our selector tool helps you to find the most relevant journal

- We provide round the clock customer support

- Convenient online submission

- Thorough peer review

- Inclusion in PubMed and all major indexing services

- Maximum visibility for your research

Submit your manuscript at www.biomedcentral.com/submit 